\title{
Heme Peroxidases at Unperturbed and Inflamed Mucous Surfaces
}

\author{
Jürgen Arnhold
}

check for

updates

Citation: Arnhold, J. Heme Peroxidases at Unperturbed and Inflamed Mucous Surfaces. Antioxidants 2021, 10, 1805. https:// doi.org/10.3390/antiox10111805

Academic Editor: Carlo Cervellati

Received: 19 October 2021

Accepted: 10 November 2021

Published: 12 November 2021

Publisher's Note: MDPI stays neutral with regard to jurisdictional claims in published maps and institutional affiliations.

Copyright: (C) 2021 by the author. Licensee MDPI, Basel, Switzerland. This article is an open access article distributed under the terms and conditions of the Creative Commons Attribution (CC BY) license (https:/ / creativecommons.org/licenses/by/ $4.0 /)$.
Medical Faculty, Institute of Medical Physics and Biophysics, Leipzig University, 04107 Leipzig, Germany; juergen.arnhold@medizin.uni-leipzig.de

\begin{abstract}
In our organism, mucous surfaces are important boundaries against the environmental milieu with defined fluxes of metabolites through these surfaces and specific rules for defense reactions. Major mucous surfaces are formed by epithelia of the respiratory system and the digestive tract. The heme peroxidases lactoperoxidase (LPO), myeloperoxidase (MPO), and eosinophil peroxidase (EPO) contribute to immune protection at epithelial surfaces and in secretions. Whereas LPO is secreted from epithelial cells and maintains microbes in surface linings on low level, MPO and EPO are released from recruited neutrophils and eosinophils, respectively, at inflamed mucous surfaces. Activated heme peroxidases are able to oxidize (pseudo)halides to hypohalous acids and hypothiocyanite. These products are involved in the defense against pathogens, but can also contribute to cell and tissue damage under pathological conditions. This review highlights the beneficial and harmful functions of LPO, MPO, and EPO at unperturbed and inflamed mucous surfaces. Among the disorders, special attention is directed to cystic fibrosis and allergic reactions.
\end{abstract}

Keywords: lactoperoxidase; myeloperoxidase; eosinophils peroxidase; mucous surfaces; inflammation; hypothiocyanite; hypochlorous acid; cystic fibrosis; allergies

\section{Introduction}

Our organism is permanently exposed to various kinds of microorganisms. With the predominant majority of these microorganisms, we are living in peaceful co-existence. The immune system controls the activities of bacteria, viruses, fungi, protozoa, parasites, etc., as well as the responses to any threat by the recruitment and activation of immune cells and the formation of antibodies [1]. In addition, proteins of the acute phase, complement, coagulation, and contact systems can be activated and closely assist the immune response [2]. These activities are directed to decrease tissue damage and to restore homeostasis of the affected tissues. Nevertheless, local or systemic inflammations can culminate with pronounced tissue destruction and pathological states in severe cases. The division of microorganisms into innocuous or harmful ones highly depends on the current immunological state of the individuals. It is well known that usually harmless microbes can provoke serious deteriorations in immunosuppressed patients $[3,4]$.

Mucous surfaces form specialized, indispensable to life compartments in the organism with their own specific rules for defense reactions [5]. Important internal surfaces are the epithelia of the upper respiratory system and the lungs (bronchia, bronchioles, and alveola), and surfaces of the digestive tract (epithelia of oral cavity, esophagus, stomach, small intestine, and colon). In addition, several glands expel their secretions at these and other surface areas. Maintaining the integrity of mucous surfaces is highly essential for the long-term functioning and survival of the organism. On the one hand, these epithelia form a physical barrier. On the other hand, they are embedded in multiple functional processes with defined fluxes of certain metabolites through these surfaces.

Heme peroxidases are known to contribute to immune protection in humans and many other organisms. In mucous linings and secretions, lactoperoxidase (LPO) is an essential component to maintain pathogen contamination on low level [6]. Myeloperoxidase (MPO) 
is another heme peroxidase that is enriched in polymorphonuclear leukocytes, also known as neutrophils $[7,8]$. At inflamed sites, these cells recognize, phagocytose, and degrade microbes and fungi under the involvement of MPO. A third peroxidase, the eosinophil peroxidase (EPO) contributes to killing larger pathogens such as helminths by eosinophil granulocytes (eosinophils) [9]. Under inflammatory conditions, immune cell-derived heme peroxidases are also discussed for their involvement in destructive reactions. In particular, MPO is known to exert a dual role as a beneficial or damaging agent in immune reactions [10].

This review highlights the participation of heme peroxidases in immune reactions at unperturbed and inflamed mucous surfaces and the involvement of peroxidase-derived agents in the pathogenesis of diseases of mucous epithelia.

\section{Organization of Immune Defense at Mucous Surfaces}

At mucous surfaces, the immune defense is directed to ensure the physical integrity of the epithelium and to protect adjacent tissues from any threat without disturbing specific metabolic exchange processes within and through the epithelial layer. Two major activities of epithelial cells contribute to immune protection: (i) Gel-forming mucins and an arsenal of antimicrobial agents, including LPO and thiocyanate, are permanently secreted by epithelial cells into the luminal space, and (ii) activation and damage of epithelial cells can induce immune defense reactions.

\subsection{Secretion of Immune-Protective Agents}

Different immune-protecting agents are secreted by the epithelial cells of mucous surfaces (Figure 1). These agents are directed to maintain homeostatic conditions in the surface epithelia and adjacent luminal space.

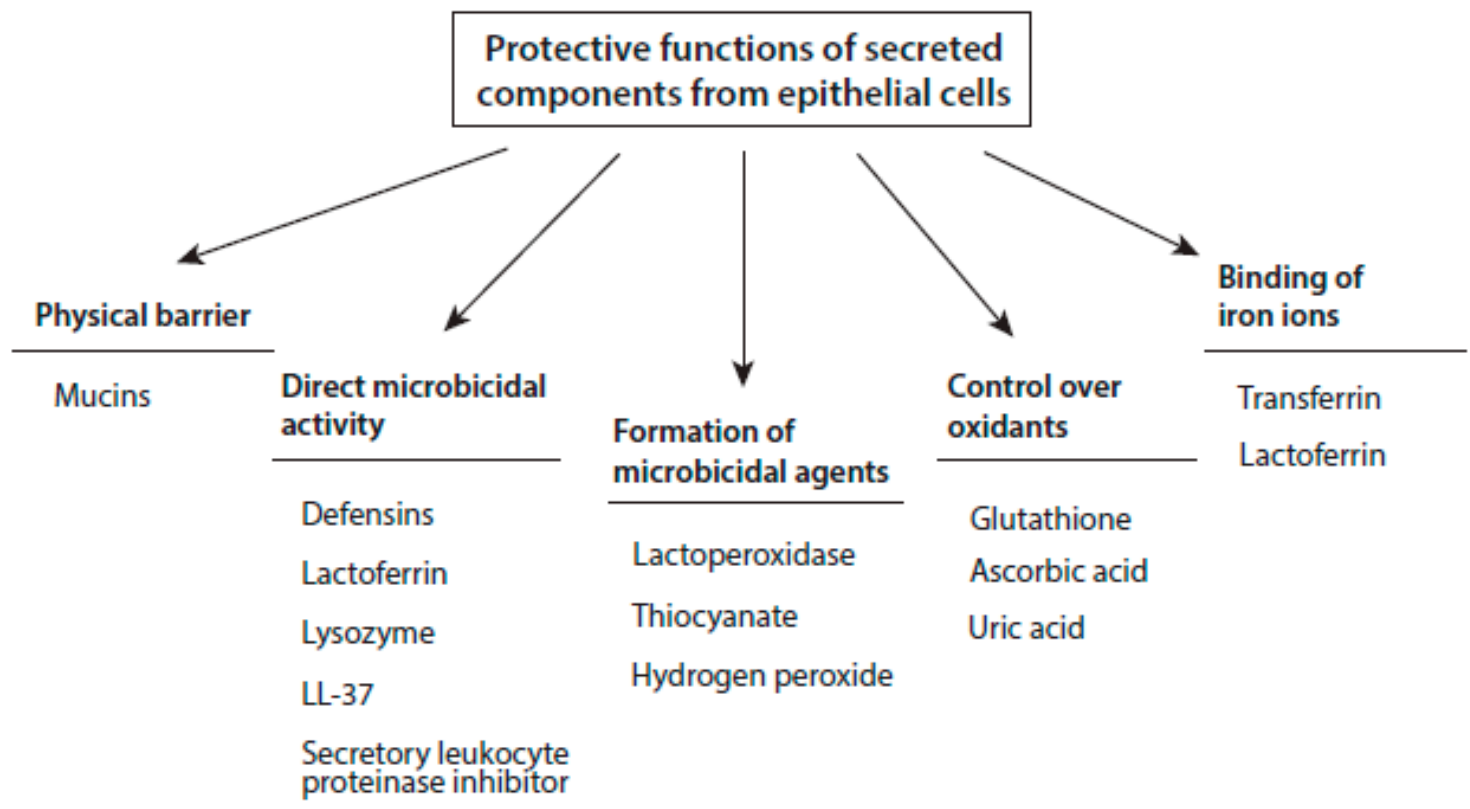

Figure 1. Major immune-protective functions of agents secreted from epithelial cells of mucous surfaces.

The epithelia of inner surfaces are covered by a thin mucous layer, in which the main components are produced and released by epithelial Goblet cells and mucous cells in submucosal glands [11]. This mucous lining consists of polymeric glycoproteins, the mucins that form a network with viscoelastic and lubricious properties. In mucins, oligosaccharide units are linked to a polypeptide backbone. Non-glycosylated regions of mucin chains enable interchain disulfide crosslinking and are vulnerable to proteolysis [12,13]. Mucin molecules and rheology of the mucous layer differ at various mucosal epithelia in dependence on their key physiological functions [14,15]. 
Intact mucin networks protect the underlying cell layer from dryness, allow the selective permeability of gases and nutrients, and represent a physical barrier that keeps commensal microorganisms and pathogens away from the epithelial surface $[5,14,16]$. Usually, the mucous lining is free of or contains only a few pathogens.

Airway epithelia are covered by a periciliary and a mucous layer. The first layer is responsible for lubrication of ciliary beat, transport of the mucous layer, and represents a size exclusion barrier. In the mucous layer, mucins form a viscoelastic, isotonic fluid. Both layers act together in mucociliary elimination of inhaled pathogens [12,16].

In the lungs, there is an intense cross-talk between epithelial cells and alveolar macrophages to maintain homeostasis [17]. Alveolar macrophages are maintained in a quiescent state by neighbored epithelial cells under non-activating conditions [18]. This regulatory interaction is lost due to epithelial damage or by the presence of pathogens. Lung epithelial cells are able to secrete a wide variety of antimicrobial agents such as $\beta$-defensins, lactoferrin, LL-37, lysozyme, and secretory leukocyte proteinase inhibitor. In addition, they can produce various surfactant proteins that are involved in pathogen clearance [19]. Macrophages phagocytose undergoing cells, cell debris, and pathogens and contribute to the regulation of the inflammatory process [20].

In the mucous lining, additional protection is given against potential invaders by bactericidal components such as resistin-like molecule $\beta$ and zymogen granulae protein 16 that are secreted from Goblet cells [21,22], as well as by antifungal peptides such as histatins and MUC7 12-mer [23,24]. In the small intestine, Paneth cells release bactericidal defensins, lysozyme, and cryptdins into the gut lumen [25].

In addition to these directly acting microbicidal agents, components of the lactoperoxidase$\mathrm{H}_{2} \mathrm{O}_{2}$-thiocyanate system are secreted at mucous epithelia. As outlined in more detail in Section 4, this system exerts immune protection in mucous linings and secretions by synthesis of the antimicrobial agent hypothiocyanite/hypothiocyanous acid.

Mucous epithelial cells secrete glutathione, which is a major protective agent against oxidants. Particular high levels of glutathione are found in airway lining fluid [26]. In lung epithelial fluid, other abundant species with antioxidative properties are ascorbate and uric acid [27]. Lactoferrin is another protective component at mucous surfaces. It exhibits antibacterial activity against Gram-negative bacteria and prevents bacterial growth by sequestration of free iron ions [28]. Moreover, the iron-binding protein transferrin is enriched in human bronchoalveolar fluid [29].

\subsection{Immune-Activating Mechanisms at Mucous Surfaces}

While secretory processes from epithelial cells are usually sufficient to warrant homeostatic conditions in the surrounding luminal space, the activation of the host's immune system is important when any molecular patterns are sensed by pattern recognition receptors in the epithelium. Under inflammatory conditions, both pathogen-associated molecular patterns (PAMPs) and damage-associated molecular patterns (DAMPs, also known as alarmins) initiate the recruitment and activation of immune cells to the inflamed area [30-32].

Immune response depends on the pathogen type and the degree of cell and tissue destruction. According to the dominating pathogens, three major routes for immune response are differentiated [33]. The type 1 immune response with monocytes as effector cells is directed to protect cells and tissues against intracellular bacteria, protozoa, and viruses. Helminths and other extracellular parasites are targeted by basophils, mast cells, and eosinophils in the type 2 immune response. In a third route, neutrophils are mainly involved to recognize and kill extracellular bacteria and fungi. These pathways are characterized by their own set of secreted cytokines and immunoglobulins, as well as by the development of typical disease scenarios in the case of dysregulation. A general problem in the thorough description of alterations at diseased mucous surfaces results from the fact that several routes of immune response can concomitantly be activated. 
Although all of the three types of immune response can play a role at inflamed mucous surfaces, the attention is often focused on type 2 immune reactions as parasites, helminths, and viruses target predominantly mucous epithelial surfaces. Stressed and damaged epithelial cells release several molecules playing the role of DAMPs and initiators of allergic inflammations. Among them are thymic stromal lymphopoietin (TSLP), IL-33, and, IL-25 [34-36]. These epithelial-derived cytokines regulate a broad spectrum of immune cell responses and are involved most of all in the induction of Th2 cells, production of IgE by B-lymphocytes, elicitation and activation of mast cells, eosinophils, and basophils [37].

Concerning heme peroxidases, LPO is commonly available in secretions also under normal, non-inflammatory conditions. The other two peroxidases, MPO and EPO, can be found at inflamed areas of mucous surfaces when neutrophils and eosinophils are additionally recruited and activated.

\section{Important Properties and Reactions of Heme Peroxidases}

\subsection{Selected Structural Properties}

Whereas LPO and EPO are monomeric proteins [38,39], MPO has a dimeric structure, where two identical subunits are linked by a disulfide bridge and each subunit consists of a light and heavy polypeptide chain [40]. At neutral $\mathrm{pH}$ values, all of the three heme peroxidases are cationic proteins. The isoelectric point of LPO is about 9.5 [41]. The corresponding values for the two other peroxidases are usually given as $>10$ for MPO [42] or $>11$ in the case of EPO [43]. Myeloperoxidase is rich in surface-located lysine and arginine residues, which are important for the interaction with negatively charged proteins, glycosaminoglycans, and DNA [44].

Common to all of the three mentioned peroxidases, MPO, EPO, and LPO, is the presence of a heme group (ferric protoporphyrin IX) in each monomeric unit that is coupled in contrast to other heme proteins (such as hemoglobin or cytochromes) by two (LPO, EPO) or three (MPO) covalent linkages to the apoprotein, as shown by X-ray data (MPO, LPO) and biochemical analysis (EPO) $[39,45,46]$. As a result, the heme becomes more or less bow-shaped, the heme iron is marginally shifted from its central position to the proximal side, electrons of the porphyrin ring are additionally stressed, and the position of the Soret band is redshifted. The strongest effects on heme are observed in the case of MPO. These heme deteriorations provide the basis for the extraordinary reactivity of heme peroxidases including the oxidation of (pseudo)halides and the oxidation of numerous small molecules. In Table 1, selected structural peculiarities of MPO, EPO, and LPO are summarized.

Table 1. Selected structural properties of heme peroxidases.

\begin{tabular}{cccc}
\hline Property & MPO & EPO & LPO \\
\hline Overall structure & dimeric [40] & monomeric [38] & monomeric [39] \\
\hline Molecular weight & $144 \mathrm{kDa}[40]$ & $71 \mathrm{kDa}$ [38] & $\begin{array}{c}77.5 \mathrm{kDa} \text { [11], } \\
\text { Faraji 2017 }\end{array}$ \\
\hline$p$-value & $>10$ [42] & $>11$ [43] & 9.5 [41] \\
\hline $\begin{array}{c}\text { Number of linkages } \\
\text { between heme and } \\
\text { apoprotein }\end{array}$ & 3 [46] & 2 [45] & [39] \\
\hline $\begin{array}{c}\text { Heme bending } \\
\text { Displacement of central } \\
\text { heme iron to the proximal } \\
\text { side }\end{array}$ & stronger as in EPO & slight & slight \\
\hline Soret band location & $0.2 \AA$ [46] & unknown & $0.1 \AA$ [39] \\
\hline
\end{tabular}




\subsection{Formation of Compound I}

Depending on heme iron valency and the presence of a radical moiety, several redox states of heme peroxidases can be differentiated. In the resting enzyme, heme iron is in the ferric state. Upon reaction with hydrogen peroxide $\left(\mathrm{H}_{2} \mathrm{O}_{2}\right)$, the so-called Compound $\mathrm{I}$ is formed from the ferric enzyme. In Compound I, oxygen is coupled to ferryl iron by a double bond and a further electron is taken from the porphyrin ring that represents a porphyryl cation radical [50]. The highly reactive Compound I is able to catalyze two- and one-electron oxidations of numerous small substrates. In the case of LPO Compound I, the radical moiety of the porphyrin ring can spontaneously be transferred to the apoprotein, most likely a tyrosine residue, forming an apoprotein radical that is known as Compound $I^{*}[51,52]$. This radical transfer is unknown for MPO and EPO.

\subsection{Halogenation Cycle}

The important substrates for the two-electron oxidation of Compound I of MPO, EPO, and LPO are (pseudo)halides. Their oxidation yields hypohalous acids or hypothiocyanite $\left(\mathrm{OSCN}^{-}\right)$as major products. Upon these two-electron oxidations, Compound I is reconverted into the ferric enzyme form. The sequence of the two reactions (ferric enzyme $\rightarrow$ Compound I $\rightarrow$ ferric enzyme) is called the halogenation cycle (Figure 2).

\section{Halogenation cycle}

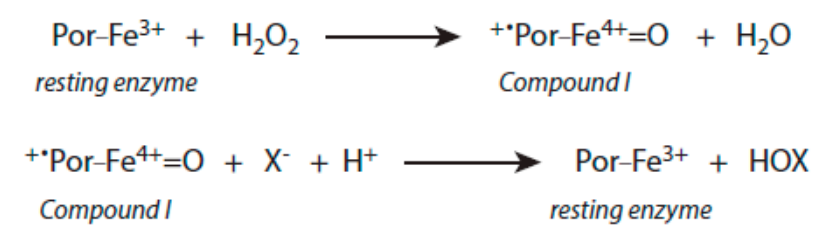

\section{Peroxidase cycle}

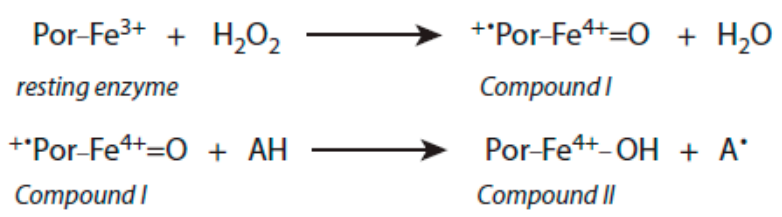

alternative pathway (only in LPO):

Compound I $\longrightarrow$ Compound I*

Compound $\mathrm{I}^{*}+\mathrm{AH} \longrightarrow$ Compound II $+\mathrm{A}^{*}$

Por- $\mathrm{Fe}^{4+}-\mathrm{OH}+\mathrm{AH} \longrightarrow \mathrm{Por}_{-} \mathrm{Fe}^{3+}+\mathrm{A}^{\cdot}+\mathrm{H}_{2} \mathrm{O}$

Compound II resting enzyme

Figure 2. Halogenation and peroxidase cycles of heme peroxidases. Further explanations are given in the text. Por-Fe denotes the porphyrin-iron complex. $\mathrm{X}^{-}$stands for $\mathrm{Cl}^{-}, \mathrm{Br}^{-}, \mathrm{I}^{-}$, and $\mathrm{SCN}^{-}$. $\mathrm{HOX}$ is the corresponding (pseudo)hypohalous acid. $\mathrm{AH}$ is an oxidizable substrate, and $\mathrm{A}^{-}$the resulting substrate radical.

The three heme peroxidases differ in their ability to oxidize (pseudo)halides. At neutral $\mathrm{pH}$ values, only MPO oxidizes $\mathrm{Cl}^{-}$at a reasonable rate [47]. Bromide is well oxidized by MPO and EPO [47,48] and to a minor degree by LPO [51]. Oxidation of $\mathrm{I}^{-}$and thiocyanate $\left(\mathrm{SCN}^{-}\right)$is known for all of the three heme peroxidases $[47,48,51]$. Lactoperoxidase Compound $\mathrm{I}^{*}$ is unable to oxidize halides and thiocyanate. With increasing acidity, rate constants increase for (pseudo)halide oxidation by MPO and EPO [47,48]. 
Moreover, at pH 5, EPO is able to oxidize $\mathrm{Cl}^{-}$[48]. Furthermore, the ability of LPO to oxidize $\mathrm{SCN}^{-}$increases under slightly acidic conditions [49].

\subsection{Peroxidase Cycle}

In one-electron oxidations of substrates by Compound I of these peroxidases (and also by Compound I* of LPO) Compound II is formed, which contains an oxo-ferryl heme iron, but no radical moiety neither in the porphyrin ring nor the apoprotein [40]. The list of potential one-electron substrates of Compound I is long. The important one-electron substrates for MPO are selected polyphenols, urate, tyrosine, tryptophan, sulfhydryls, indole derivatives, nitrogen oxide, nitrite, $\mathrm{H}_{2} \mathrm{O}_{2}$, and superoxide anion radicals [53-58].

The reduction of Compound II to the ferric enzyme is also coupled with the oneelectron oxidation of substrates. In contrast to Compound I, the ability of Compound II for substrate oxidation is restricted to a limited number of substrates. As a result of this restriction, heme peroxidases can accumulate as inactive Compound II in the absence of substrates that are well oxidized by Compound II. For MPO and LPO, efficient substrates for Compound II are superoxide anion radicals, urate, tyrosine, serotonin, nitrite, and selected flavonoids [53,57-63]. In the presence of these substrates, an accumulation of Compound II can be avoided and the halogenation activity can be enhanced.

The reaction sequence (ferric enzyme $\rightarrow$ Compound I $\rightarrow$ Compound II $\rightarrow$ ferric enzyme) is known as the peroxidase cycle (Figure 2). In the case of LPO, the conversion of Compound I to Compound II can also occur via Compound I*, which is formed from Compound I by an isoelectronic transition.

\section{The Lactoperoxidase-Hydrogen Peroxide-Thiocyanate System in Mucous Fluids and Secretions}

\subsection{Distribution of $L P O$}

Lactoperoxidase is synthesized in the epithelial cells of secretory surfaces and secreted into the luminal space. This protein is found in the epithelial lining covering the upper airways, and in secretions such as milk, tears, and saliva [64]. In the gut, LPO is expressed in the mouse epithelium, but not in human epithelial cells [65]. Evidently, in the human small intestine and distal colon, the complex immunological defense is ensured without the participation of LPO.

\subsection{The LPO Knockout Mouse}

In mutant mice, the total knockout of the LPO gene causes complex multisystem inflammatory pathology as assessed by histological examination [66], namely inflammation of myocardium, coronary artery, aorta, and cardiac valves. Moreover, other pathologies concern inflammatory airway disease, glomerulonephritis, inflammation in the digestive system, and the development of tumors in different organs [66]. LPO knockout mice have a limited lifetime. About $30 \%$ of these mice died before they reached 1 year of age or needed to be killed for human endpoints. Both overweight (and even obese) as well as underweight mice were observed in the LPO knockout cohort [66].

These data indicate that LPO is an important component of immunological control at mucous surfaces and in secretions that can only partly be compensated by other defense mechanisms.

\subsection{Formation of Hypothiocyanite/Hypothiocyanous Acid}

At mucous surfaces and in secretions, $\mathrm{LPO}$ is known to act together with $\mathrm{H}_{2} \mathrm{O}_{2}$ and $\mathrm{SCN}^{-}$. These components are shortly referred to as the $\mathrm{LPO}-\mathrm{H}_{2} \mathrm{O}_{2}-\mathrm{SCN}^{-}$system. Two major aspects are under discussion about the mode of action of this system in antiinflammatory defense at these loci: (i) The formation of the microbicidal hypothiocyanite/hypothiocyanous acid; and (ii) the control over the $\mathrm{H}_{2} \mathrm{O}_{2}$ level.

In the presence of low micromolar levels of $\mathrm{H}_{2} \mathrm{O}_{2}$, ferric $\mathrm{LPO}$ is converted into Compound I that oxidizes $\mathrm{SCN}^{-}$to $\mathrm{OSCN}^{-}$in a very rapid reaction [51]. The latter ion is 
in equilibrium with its protonated form, the hypothiocyanous acid (HOSCN) with a $p$ value of 5.3 [67] or 4.85 [68]. In contrast to $\mathrm{HOCl}[69,70]$ and $\mathrm{HOBr}$ [71], the reactivity of $\mathrm{OSCN}^{-} / \mathrm{HOSCN}$ is more specific. It predominantly reacts with targets containing accessible sulfhydryl groups or selenocysteine residues [72,73]. Moreover, the uncharged HOSCN is able to permeate through membranes and thus, can enter intracellular compartments. In microorganisms, intracellular glutathione and sulfhydryls in cytosolic enzymes are pronounced targets for oxidized $\mathrm{SCN}^{-}[74,75]$. In secretions, $\mathrm{HOSCN}$ can even penetrate into biofilms $[74,75]$.

In epithelial cells, cytosolic and mitochondrial thioredoxin reductases are known to metabolize $\mathrm{HOSCN}$ to $\mathrm{SCN}^{-}$and $\mathrm{H}_{2} \mathrm{O}$ and thus, protect these cells from side reactions of HOSCN [76]. Bacteria are unable to inactivate HOSCN in this way [76]. With these activities, the $\mathrm{LPO}-\mathrm{H}_{2} \mathrm{O}_{2}-\mathrm{SCN}^{-}$system contributes to the control over microorganisms at numerous mucous surfaces and in secretions.

\subsection{Secretion of Thiocyanate}

Thiocyanate is also secreted from epithelial cells of mucous surfaces and secretory glands. In circulating blood, $\mathrm{SCN}^{-}$concentration is about 10-120 $\mu \mathrm{M}[77,78]$. The blood level of $\mathrm{SCN}^{-}$depends on the patient's smoking habit and diet regime. Higher $\mathrm{SCN}^{-}$ serum concentrations are found in persons smoking heavily or with a strong cabbage diet. In secretory epithelial cells, $\mathrm{SCN}^{-}$is enriched from capillary blood by an active transport mechanism via the sodium-iodide symporter [79]. This transporter, well known from thyroid epithelium, accumulates both $\mathrm{SCN}^{-}$and $\mathrm{I}^{-}$in epithelial cells. Moreover, iodide is well oxidized by LPO Compound I under the formation of an arsenal of oxidized iodine species [80]. However, these products play only a minor role in mucosal defense due to the low abundance of $\mathrm{I}^{-}$in the blood. The plasma level of $\mathrm{I}^{-}$is below $100 \mathrm{nM}$ [81].

Secretion of $\mathrm{SCN}^{-}$(and also ${ }^{-}$) from epithelial cells at the apical site occurs through several mechanisms [82]. The main focus is usually directed on two anion channels, cystic fibrosis trans-membrane conductance regulator (CFTR) and pendrin. The transport of $\mathrm{SCN}^{-}$ through CFTR is stimulated by cAMP, whereas pendrin is sensitive to interleukin-4 [83]. A third mechanism of $\mathrm{SCN}^{-}$transport is mediated by $\mathrm{Ca}^{2+}$-dependent $\mathrm{Cl}^{-}$channels [83].

In saliva, $\mathrm{SCN}^{-}$concentrations are around $0.5-4 \mathrm{mM}[84,85]$, while the $\mathrm{I}^{-}$value is reported to be 5-22 $\mu \mathrm{M}$ [84]. High micromolar $\mathrm{SCN}^{-}$concentrations were found in tears (150 $\mu \mathrm{M}$ [86]), nasal airway fluid (300-450 $\mu \mathrm{M}$ [87]), and lung airway fluid (270-650 $\mu \mathrm{M}$ [88]).

\subsection{Sources for Hydrogen Peroxide}

There are several sources for $\mathrm{H}_{2} \mathrm{O}_{2}$ in mucous linings. Duox1 and Duox2 are assumed to be the main sources of $\mathrm{H}_{2} \mathrm{O}_{2}$ in the mucous lining. These enzymes are expressed in the apical plasma membrane of airway epithelial cells [89-91]. They use electrons from NADPH to reduce dioxygen in order to superoxide anion radicals, which dismutate spontaneously or are catalyzed by superoxide dismutases to $\mathrm{H}_{2} \mathrm{O}_{2}$ and $\mathrm{O}_{2}$.

Xanthine oxidase is an additional enzyme that reduces $\mathrm{O}_{2}$ to superoxide anion radicals and $\mathrm{H}_{2} \mathrm{O}_{2}$ [92]. Enhanced activities of xanthine oxidase were observed in inflammatory airways epithelia $[93,94]$.

Few bacteria, which can colonize at mucous surfaces, are known to produce $\mathrm{H}_{2} \mathrm{O}_{2}$ [95], namely Streptococcus pneumoniae and a few other Streptococcus species [96,97]. Microbial $\mathrm{H}_{2} \mathrm{O}_{2}$ inhibits inflammasome-dependent processes of innate immune defense and thus, promotes bacterial colonization [97].

\subsection{Control over Hydrogen Peroxide}

The second major aspect of the mode of action of the $\mathrm{LPO}-\mathrm{H}_{2} \mathrm{O}_{2}-\mathrm{SCN}^{-}$system concerns the control over the $\mathrm{H}_{2} \mathrm{O}_{2}$ level by LPO. The increased $\mathrm{H}_{2} \mathrm{O}_{2}$ level is assumed to favor oxidative stress and numerous oxidative damage reactions of biological components most probably via the Fenton reaction. 
In $\mathrm{SCN}^{-}$oxidation, $\mathrm{LPO}$ cycles permanently between the ferric form and Compound I and thus, utilizes $1 \mathrm{~mol} \mathrm{H}_{2} \mathrm{O}_{2}$ per 1 mol oxidized $\mathrm{SCN}^{-}$. This (pseudo)halogenation cycle can be abated at low $\mathrm{SCN}^{-}$level in mucous linings. Under these conditions, the probability rises for the spontaneous transformation of Compound I into Compound I* [51]. In addition, a broad range of substrates can be oxidized by Compound I (and also by Compound $\mathrm{I}^{*}$ ) by abstracting one electron under formation of Compound II [52]. In the absence of substrates that are able to reduce Compound II to ferric LPO, this can lead to the arrest of the enzyme as inactive Compound II. As a result of low external $\mathrm{SCN}^{-}$, the formation of microbicidal $\mathrm{OSCN}^{-} / \mathrm{HOSCN}$ is diminished and the level of $\mathrm{H}_{2} \mathrm{O}_{2}$ rises.

Hydrogen peroxide is freely permeable through biological membranes. In cells, the level of $\mathrm{H}_{2} \mathrm{O}_{2}$ is controlled by several $\mathrm{H}_{2} \mathrm{O}_{2}$ consuming enzymes such as peroxiredoxins, catalase, and glutathione peroxidase [98-100]. In mucous linings and secretions, LPO is a major agent controlling $\mathrm{H}_{2} \mathrm{O}_{2}$. In the airway lining fluid, additional control of the $\mathrm{H}_{2} \mathrm{O}_{2}$ level is carried out by the high yield of glutathione together with extracellular glutathione peroxidase [26,101].

Hydrogen peroxide reacts in the so-called Fenton reaction with transition metal ions $\left(\mathrm{Fe}^{2+}, \mathrm{Cu}^{+}\right)$under the formation of highly reactive hydroxyl radicals and/or perferryl species [102,103]. The probability for their formation rises at an enhanced $\mathrm{H}_{2} \mathrm{O}_{2}$ level and in the presence of free metal ions. In order to avoid dangerous reactions of metal ions, they are tightly controlled by several mechanisms in cells and tissues [104,105]. In airway lining fluids, transferrin is the major component for binding iron ions [29]. In secretions, lactoferrin is also able to scavenge and inactivate transition free iron ions [28].

\section{Heme Peroxidases at Inflamed Epithelia}

\subsection{Major Functions of MPO and EPO at Inflamed Loci}

With invading neutrophils, and to a minor degree with monocytes, MPO is attracted to inflamed loci. Several major functions of MPO are discussed [10]. This enzyme plays an active role during the phagocytosis of pathogens by neutrophils. It is apparently involved in the rapid $\mathrm{pH}$ increase in newly formed phagosomes and thus, provides optimal conditions for the action of serine proteases and microbicidal proteins.

In undergoing neutrophils, MPO is essential for the formation of neutrophil extracellular traps [106], where MPO and other proteins from neutrophils are tightly associated with DNA $[107,108]$. Traps are important for the defense against hyphenated fungi and microbes, independent of phagocytosis $[109,110]$.

In addition, MPO released from neutrophils attaches to negatively charged surface areas, and forms complexes with several acidic proteins and polymers [44,111-117]. It is able to penetrate into endothelial cells. Moreover, after residing at the basolateral side, it affects the bioavailability of nitrogen monoxide in blood vessels $[118,119]$. On the basis of these findings, an involvement of MPO is discussed in the pathogenesis of numerous disease scenarios including atherosclerosis, vasculitis, rheumatoid arthritis, neurodegenerative diseases, etc. [120-122].

Attachment of MPO to cell surfaces at inflamed loci can induce the formation of antibodies against this protein [123]. The so-called myeloperoxidase-antineutrophil cytoplasmic antibodies play a role in the pathogenesis of different forms of vasculitis such as glomerulonephritis [124] and vasculitis of the upper and lower respiratory tract [125].

In reactions of type 2 immune response, eosinophils are recruited and activated together with mast cells and basophils [33]. Eosinophils are involved in the inactivation and killing of larger pathogens such as helminths and other parasites [126,127]. Moreover, they exhibit pronounced antimicrobial, antiviral, and antifungal activities [128]. After contact with pathogens, they release highly cationic proteins from their granules including EPO. In targeted cells, granule proteins create toxic pores, exhibit antiviral activities, and promote oxidative stress [9]. EPO contributes to the damage of the reactions via formation of $\mathrm{HOBr}$ [129]. Furthermore, these cells are important mediators of allergic diseases [130,131]. 
Similar to neutrophils, eosinophils are also known to release DNA-containing extracellular traps, the so-called eosinophil extracellular traps $[132,133]$. In contrast to neutrophils, the underlying process of trap formation in eosinophils is accompanied by the release of free extracellular granules that can target conidia from Aspergillus fumigatus, a fungus that is very common in allergic bronchopulmonary mycoses $[134,135]$.

\subsection{Disturbed Ion Transport in Cystic Fibrosis}

In cystic fibrosis (CF), a multiorgan disease, secretion of anions from epithelial cells is disturbed as a result of genetic defects in CFTR. Mutations of the CFTR gene are classified into six main categories according to their impact on the CFTR protein. Severe CF phenotype is developed in people who are homozygous for class I, II, and III mutations [136]. In class I mutation, translation of the CFTR protein is prematurely terminated. Protein misfolding and enhanced proteasome degradation are key characteristics for class II mutations. The CFTR protein bearing class III mutation is incorporated into the plasma membrane, but is defective and exists most likely in a closed conformation. In the less severe phenotypes of classes IV to VI, functions of the anion channel are only partly disturbed. In many CF reviews, the type of CFTR mutations is not specified or CF is related to the most common $\triangle \mathrm{F} 508$ mutation [137] belonging to the class II mutation.

The apical ion channel CFTR transports $\mathrm{SCN}^{-}$, chloride, bicarbonate, glutathione, and other anions into the mucous lining [138-140]. Together with the epithelial sodium channel and other proteins, the CFTR channel contributes to the regulation of volume and composition of extraepithelial fluid. In airway CF epithelia, reduced $\mathrm{Cl}^{-}$and bicarbonate secretion and increased compensatory absorption of $\mathrm{Na}^{+}$are responsible for water loss in the periciliary layer, enhanced adherence of mucins to epithelial cells, altered mucin properties, and decreased ciliary activity [141].

Moreover, it has been assumed that $\mathrm{CF}$ is associated with a lower $\mathrm{SCN}^{-}$level in mucous linings and thus, with a decreased ability to generate the microbicidal ${ }^{-}$OSCN/HOSCN [142]. Indeed, in cell culture experiments with airway epithelial cells that are defective in the CFTR channel, the ability to kill pathogens by ${ }^{-}$OSCN/HOSCN was impaired $[139,142]$. However, the analysis of nasal airway surface liquids of persons with or without $\mathrm{CF}$ revealed no differences in $\mathrm{SCN}^{-}$concentrations between both groups [143]. Evidently, the anion transporter pendrin can compensate deficient $\mathrm{SCN}^{-}$transport by CFTR. Furthermore, pendrin is upregulated in airway epithelial cells by pro-inflammatory cytokines such as interleukin-4 $[83,144,145]$.

On the contrary, the $\mathrm{SCN}^{-}$concentration in nasal airway surface liquids was about 30 times higher than the $\mathrm{SCN}^{-}$level in the serum of both the $\mathrm{CF}$ patients and healthy individuals [143]. In airway surface liquids, a similar ratio of 30 was determined for the $\mathrm{SCN}^{-}$serum values of both the $\mathrm{CF}$ and healthy individuals [146,147].

\subsection{Alterations in Mucous Properties in Cystic Fibrosis}

In inflamed airway mucous fluids of $\mathrm{CF}$ patients, a lower $\mathrm{pH}$ of 6.8 was found as opposed to the unperturbed linings with a $\mathrm{pH}$ of 7.1 [148]. Moreover, protons were enriched in the nasal airway fluid of $\mathrm{CF}$ subjects with a $\mathrm{pH}$ of 6.57 in contrast to normal individuals with a $\mathrm{pH}$ of 7.18 [149]. In another study, equilibrium $\mathrm{pH}$ values of freshly excised sinonasal epithelia of CF patients were 7.08 as opposed to healthy subjects with a $\mathrm{pH}$ of 7.34 [150].

In the affected CF airways, a thicker and more viscous mucous was present that can result in mucous stasis, dilation of gland ducts, and reduced mucous clearance [151,152]. For the observed diminished mucociliary transport in $\mathrm{CF}$, the effect of mucous concentration is more important than airway acidification [152]. Several factors are associated with the formation of a more compact and viscous mucous in CF patients. The diminished bicarbonate transport favors a more acidic $\mathrm{pH}[150,153,154]$ and higher $\mathrm{Ca}^{2+}$ concentration in the airway surface liquid [155]. A decrease in the $\mathrm{pH}$ enhances electrostatic interactions between mucins and thus, affects mucous viscosity [156]. The elevated $\mathrm{Ca}^{2+}$ mediates a tighter cross-linking of mucin strands most likely via binding to specific domains [155,157]. 
In CF patients, airway surface fluids are more susceptible due to their increased viscosity to different opportunistic bacteria and fungi. Lung infections by Pseudomonas aeruginosa, Burkholderia cepacia, and Aspergillus fumigatus are very common in CF [136,158]. These pathogens affect predominantly immunocompromised persons. In CF, a decrease in the $\mathrm{pH}$ of airway fluids contributes also to impaired bacterial killing [159].

Since early childhood, CF patients suffer from recurrent infections in lungs and many other organs. Deficiency in CFTR favors pro-inflammatory conditions including injury of epithelial cells. This damage can be further promoted by recruited immune cells, most of all by agents released from invading neutrophils as evidenced by the presence of elastase [160,161], MPO, and MPO products such as methionine sulfoxide in airway linings [162]. In severe cases, a progressive bronchiectasis can cause death by respiratory failure.

Moreover, the presence of oxidants contributes to more compact mucin structures by inducing additional disulfide cross-links [163]. Oxidants generated by MPO from invading neutrophils are known to contribute to mucous alterations. In addition, in the sputum of CF patients, a higher yield of 3-chlorotyrosine and other tyrosine oxidation products was detected [164].

\subsection{Formation of HOCl by MPO in Inflamed Mucous Layers}

Similar to LPO, MPO is also able to oxidize $\mathrm{SCN}^{-}$. Considering (pseudo)halide concentrations in blood, it has been found that $\mathrm{MPO}$ oxidizes at $0.1 \mathrm{M} \mathrm{Cl}^{-}$and $0.1 \mathrm{mM} \mathrm{SCN}^{-}$ at a $\mathrm{pH}$ of 7, which is nearly the same amount as these anions [165]. In mucous linings, oxidation of $\mathrm{SCN}^{-}$by MPO dominates due to the markedly higher $\mathrm{SCN}^{-}$concentrations (see Section 4.4). Moreover, $\mathrm{SCN}^{-}$is rapidly oxidized by $\mathrm{HOCl}$ and competes efficiently with other targets for $\mathrm{HOCl}$ [166]. Therefore, at a first glance, the MPO-mediated formation of $\mathrm{HOCl}$ seems to be unlikely in mucous linings. The preference of $\mathrm{SCN}^{-}$over $\mathrm{Cl}^{-}$in reactions with MPO Complex I at $\mathrm{pH} 7$ is attenuated with the decreasing $\mathrm{pH}$. At $\mathrm{pH}$, the second order rate constant for the reactions of MPO Complex I with $\mathrm{SCN}^{-}$in comparison to $\mathrm{Cl}^{-}$is only 20 times higher in contrast to a ratio of nearly 400 at $\mathrm{pH} 7$ [47].

In mucous linings and epithelia, $\mathrm{pH}$ data were usually evaluated by $\mathrm{pH}$ microelectrodes or $\mathrm{pH}$-sensitive fluorophors in droplets taken from biopsies. In particular, in the case of inflamed materials, these kinds of measurements do not consider any local $\mathrm{pH}$ deviations that might result from the formation of microcompartments within the more compact mucous layer. Moreover, in the inflamed mucous of CF patients, DNA is known to be complexed with mucins [163]. Similar to negatively charged polyelectrolyte films [167], the more dense structure of mucous polymers and DNA can locally enhance the negative charges of these polymers and thus, enrich protons and other cations at local areas within the inflamed mucous layer. Interestingly, horseradish peroxidase and glucose oxidase complexed with DNA exhibit a higher activity resulting from a significant decrease of $\mathrm{pH}$ near the DNA surface [168].

The presence of MPO and MPO products was reported by several authors in the inflamed mucous of CF patients $[162,164,169,170]$. The cationic MPO resides predominantly at acidic loci [44,111-117]. Myeloperoxidase-DNA complexes are well known from neutrophil extracellular traps [106-108]. It is likely that undergoing neutrophils release traps at inflamed mucous surfaces.

The attraction of MPO to mucous polymers and the possibility of more acidic $\mathrm{pH}$ values at local areas would favor the formation of $\mathrm{HOCl}$ by the activated MPO. The ability of MPO to generate free $\mathrm{HOCl}$ rises considerably below $\mathrm{pH} 6$ [171,172].

\subsection{Allergic Inflammations}

Different allergic diseases are closely associated with the unbalanced type 2 immune response, namely allergic asthma, atopic dermatitis, food allergies, hay fever, etc. Although the pathogenesis of asthma and related allergic diseases is very complex and far from 
thorough understanding, enhanced oxidation of $\mathrm{SCN}^{-}$by heme peroxidases and, in particular, activation of $\mathrm{EPO}$ are under discussion to contribute to disease development.

An overproduction of ${ }^{-} \mathrm{OSCN} / \mathrm{HOSCN}$ has been assumed to play a role in the development of allergic inflammation in the lung, as shown in asthma model mice and asthma patients $[173,174]$. Upregulation of pendrin by IL-13 [145] and enhanced activity of heme peroxidases are responsible for this overproduction [173]. In airway epithelial cells, enhanced HOSCN activates via protein kinase A NFkB. At higher doses, HOSCN induces epithelial cell necrosis [175]. The release of IL-33 and other mediators from necrotic epithelial cells triggers an inflammatory response in airways [176,177]. Importantly, IL33 induces eosinophilia, and promotes several functions of eosinophils [178]. A vicious circle under participation of IL-13, IL-33, and ${ }^{-}$OSCN may exaggerate and prolong the type 2 immune response in allergic diseases [175].

In $\mathrm{SCN}^{-}$oxidation, both MPO and more efficiently EPO, produce in addition to the major product $\mathrm{OSCN}^{-}$, cyanate $\left({ }^{-} \mathrm{OCN}\right)$ as a minor product [179]. The latter agent, which is in equilibrium with urea, promotes carbamylation of proteins, a condition that markedly affects the function of proteins and favors endothelial dysfunction and proinflammatory processes [180-182]. Although different amino acid residues can be modified in this way, lysine residues are a preferred target for carbamylation with the formation of homocitrulline moieties. At sites of eosinophilic inflammations, an increased number of carbamylated proteins was detected [183].

In addition, activation of EPO favors bromination and nitration of target molecules. The 3-bromotyrosine, 3,5-dibromotyrosine, as well as 3-nitrotyrosine residues were detected in proteins of the airway epithelium of patients with asthma [184-186].

\subsection{Tissue Damage by Heme Peroxidases and Their Products}

During an inflammatory response, additional tissue damage can occur by agents released from the activated immune cells and undergoing tissue cells. Under chronic inflammatory conditions, the repeated release of DAMPs from necrotic tissue cells can frequently foment the inflammatory process [30]. In other words, inflammation is not terminated and tissue homeostasis is not restored adequately. Immunocompromised individuals are most of all affected by recurrent inflammations and opportunistic infections $[3,187,188]$. In the host's tissues, there is a tight balance between the damage by agents from immune and necrotic cells and the already existing mechanisms to resist and inactivate these destructive agents [1]. A shift in this balance towards damaging processes due to insufficiency or exhaustion of the host's defense mechanisms favors chronic conditions and disease processes with long-lasting inflammations. Examples for the interplay between potentially damaging agents and antagonizing principles are given in reference [10].

The major focus will be directed here on the potential role of MPO and EPO and their products in the damage of epithelial cells of mucous surfaces under chronic inflammatory conditions. Activated neutrophils and eosinophils release potential cytotoxic agents at inflammatory loci. In addition to MPO and MPO-derived oxidants, neutrophils participate in destructive reactions with numerous proteolytic enzymes such as elastase, cathepsin G, proteinase 3, lysozyme, collagenase, and gelatinase and the formation of superoxide anion radicals and $\mathrm{H}_{2} \mathrm{O}_{2}$ [10]. Cytotoxic eosinophil agents include EPO and EPO products, major basic proteins, eosinophil-derived neurotoxins, eosinophil cationic proteins, superoxide anion radicals, and $\mathrm{H}_{2} \mathrm{O}_{2}$ [9]. Therefore, heme peroxidases do not act alone in tissue damage, but in concert with other destructive components. It is very challenging to predict which agents predominate preferentially in damaging reactions. This highly depends on the individual status of antagonizing components in the host's cells and tissues.

In mucous linings, another set of antagonizing agents is present that can deactivate toxic components in comparison with other body fluids. In blood, MPO released from neutrophils is antagonized by the plasma protein ceruloplasmin, forming a tight inhibitory complex with MPO [189-193]. Moreover, ceruloplasmin forms an inhibitory complex with 
EPO [193]. Only minor amounts of ceruloplasmin were detected in the airway lining fluid [194].

Heme peroxidases can contribute to the formation of hypohalous acids and hypothiocyanite in order to damage the reactions. In mucous lining fluids, glutathione deactivates these halogenated species and functions as a cofactor for extracellular glutathione peroxidase to reduce $\mathrm{H}_{2} \mathrm{O}_{2}[26,101]$. In healthy individuals, glutathione levels of the airway lining fluid are more than 100-fold higher than in the plasma [26]. In addition to antioxidative activities, this extracellular glutathione pool is a reservoir of cysteine for the synthesis processes in epithelial cells [195]. Several pathological conditions are known with a reduced level of glutathione in airway mucous linings, namely CF and idiopathic pulmonary fibrosis [196,197]. Therefore, a reduced level of extracellular glutathione attenuates protection against $\mathrm{HOCl}$ and $\mathrm{HOBr}$, and worsens the control over ${ }^{-} \mathrm{OSCN} / \mathrm{HOSCN}$ and $\mathrm{H}_{2} \mathrm{O}_{2}$.

\section{Conclusions}

As important components of immune reactions, the heme peroxidases LPO, MPO, and EPO and their products contribute to the protection against pathogens. On the other hand, they can be involved in different pathologies concerning secretory mucous epithelia. These opposite activities of heme peroxidases reflect the general situation of immune defense. Aggressive metabolites have to be used to control and combat against pathogens. Under certain conditions, these metabolites can be directed against the host's own cells and tissues.

Mucous epithelial cells secrete a variety of immune-protective agents, namely major agents $\mathrm{LPO}, \mathrm{H}_{2} \mathrm{O}_{2}$, and $\mathrm{SCN}^{-}$, which produce bactericidal ${ }^{-} \mathrm{OSCN} / \mathrm{HOSCN}$, as well as mucins, glutathione, and transferrin. In unperturbed mucous linings, secreted components maintain microorganisms under control and scavenge potential toxic agents. Alterations in the composition of mucous linings, as well as damage of epithelial cells promote the development of inflammatory processes. In CF, the secretion of anions such as chloride, glutathione, bicarbonate, and $\mathrm{SCN}^{-}$is disturbed due to the defective CFTR channels. Therefore, serious alterations in mucous properties result, which can favor colonization of microbes on mucous surfaces. On the other hand, damage of epithelial cells of mucous surfaces is associated with the induction of type 2 immune response, including the recruitment and activation of eosinophils. Moreover, overproduction of ${ }^{-} \mathrm{OSCN} / \mathrm{HOSCN}$, carbamylation of proteins, and appearance of brominated and nitrated amino acid residues can contribute to epithelial cell necrosis. The latter mechanisms are discussed in the pathogenesis of allergies such as asthma.

At inflammatory sites, invading leukocytes release MPO and EPO. Unlike LPO, these two heme peroxidases are able to produce the powerful oxidants $\mathrm{HOCl}$ and $\mathrm{HOBr}$. In inflamed mucous linings, the chlorinating activity of MPO is apparently favored by complexes of MPO with DNA, the resulting decrease of local $\mathrm{pH}$, by glutathione deficiency, and when competing effects by $\mathrm{SCN}^{-}$are limited. Further research is highly necessary to verify these preliminary conclusions. Similar corollaries are valid for the participation of EPO and EPO products in disease progression at mucous surfaces.

Funding: This research received no external funding.

Institutional Review Board Statement: Not applicable.

Informed Consent Statement: Not applicable.

Data Availability Statement: Data is contained within the article.

Conflicts of Interest: The authors declare no conflict of interest. 


\section{References}

1. Arnhold, J. Immune response and tissue damage. In Cell and Tissue Destruction. Mechanisms, Protection, Disorders; Academic Press: London, UK; San Diego, CA, USA; Cambridge, MA, USA; Oxford, UK, 2020; pp. 155-204. [CrossRef]

2. Arnhold, J. Acute-phase proteins and additional protective systems. In Cell and Tissue Destruction. Mechanisms, Protection, Disorders; Academic Press: London, UK; San Diego, CA, USA; Cambridge, MA, USA; Oxford, UK, 2020; pp. 205-228. [CrossRef]

3. Sepkowitz, K.A. Opportunistic infections in patients with and patients without acquired immunodeficiency syndrome. Clin. Infect. Dis. 2002, 34, 1098-1107. [CrossRef] [PubMed]

4. Orlicka, K.; Barnes, E.; Culver, E.L. Prevention of infection caused by immunosuppressive drugs in gastroenterology. Ther. Adv. Chronic Dis. 2013, 4, 167-185. [CrossRef]

5. Authimoolam, S.P.; Dziubla, T.D. Biopolymeric mucin and synthetic polymer analogs: Their structure, function and role in biomedical applications. Polymers 2016, 8, 71. [CrossRef] [PubMed]

6. Flemmig, J.; Gau, J.; Schlorke, D.; Arnhold, J. Lactoperoxidase as a potential drug target. Expert Opin. Ther. Targets 2016, 20, 447-461. [CrossRef]

7. Klebanoff, S.J. Myeloperoxidase: Friend and foe. J. Leukoc. Biol. 2005, 77, 598-625. [CrossRef]

8. Arnhold, J.; Flemmig, J. Human myeloperoxidase in innate and acquired immunity. Arch. Biochem. Biophys. 2010, 500, 92-106. [CrossRef]

9. Rothenberg, M.E.; Hogan, S.P. The eosinophil. Annu. Rev. Immunol. 2006, 24, 147-174. [CrossRef]

10. Arnhold, J. The dual role of myeloperoxidase in immune response. Int. J. Mol. Sci. 2020, 21, 8057. [CrossRef] [PubMed]

11. Rogers, D.F. Airway goblet cells: Responsive and adaptable front-line defenders. Eur. Respir. J. 1994, 7, 1690-1706. [CrossRef]

12. Thornton, D.J.; Rousseau, K.; McGuckin, M.A. Structure and function of the polymeric mucins in airways mucus. Annu. Rev. Physiol. 2008, 70, 459-486. [CrossRef]

13. Sigurdsson, H.H.; Kirch, J.; Lehr, C.M. Mucus as a barrier to lipophilic drugs. Int. J. Pharm. 2013, 453, 56-64. [CrossRef]

14. Knoop, K.A.; Newberry, R.D. Goblet cells: Multifaceted players in immunity at mucosal surfaces. Mucosal Immunol. 2018, 11, 1551-1557. [CrossRef]

15. Morrison, C.B.; Markovetz, M.R.; Ehre, C. Mucus, mucins, and cystic fibrosis. Pediatr. Pulmonol. 2019, 54, S84-S96. [CrossRef]

16. Button, B.; Cai, L.-H.; Ehre, C.; Kesimer, M.; Hill, D.B.; Sheehan, J.K.; Boucher, R.C.; Rubinstein, M. Periciliary brush promotes the lung health by separating the mucus layer from airway epithelia. Science 2012, 337, 937-941. [CrossRef] [PubMed]

17. Bissonnette, E.Y.; Lauzon-Joset, J.-F.; Debley, J.S.; Ziegler, S.F. Cross-talk between alveolar macrophages and lung epithelial cells is essential to maintain lung homeostasis. Front. Immunol. 2020, 11, 583042. [CrossRef]

18. Mayer, A.K.; Bartz, H.; Fey, F.; Schmidt, L.M.; Dalpke, A.H. Airway epithelial cells modify immune responses by inducing an anti-inflammatory microenvironment. Eur. J. Immunol. 2008, 38, 1689-1699. [CrossRef]

19. Bals, R.; Hiemstra, P.S. Innate immunity in the lung: How epithelial cells fight against respiratory pathogens. Eur. Respir. J. 2004, 23, 327-333. [CrossRef]

20. Mosser, D.M.; Edwards, J.P. Exploring the full spectrum of macrophage activation. Nat. Rev. Immunol. 2008, 8, 958-969. [CrossRef] [PubMed]

21. Bergström, J.H.; Birchenough, G.M.H.; Katona, G.; Schroeder, B.O.; Schütte, A.; Ermund, A.; Johansson, M.E.V.; Hansson, G.C. Gram-positive bacteria are held at a distance in the colon mucus by the lectin-like protein ZG16. Proc. Natl. Acad. Sci. USA 2016, 113, 13833-13838. [CrossRef]

22. Propheter, D.C.; Chara, A.L.; Harris, T.A.; Ruhn, K.A.; Hooper, L.V. Resistin-like molecule $\beta$ is a bactericidal protein that promotes spatial segregation of the microbiota and the colonic epithelium. Proc. Natl. Acad. Sci. USA 2017, 114, 11027-11033. [CrossRef] [PubMed]

23. Muralidharan, R.; Bobek, L.A. Antifungal activity of human salivary mucin-derived peptide, muc7 12-mer, in a murine model of oral candidiasis. J. Pept. Res. 2005, 66, 82-89. [CrossRef]

24. Torres, S.R.; Garzino-Demo, A.; Meiller, T.F.; Meeks, V.; Jabra-Rizk, M.A. Salivary histatin-5 and oral fungal colonisation in HIV+ individuals. Mycoses 2009, 52, 11-15. [CrossRef] [PubMed]

25. Farin, H.F.; Karthaus, W.R.; Kujala, P.; Rakhshandehroo, M.; Schwank, G.; Vries, R.G.J.; Kalkhoven, E.; Nieuwenhuis, E.E.S.; Clevers, H. Paneth cell extrusion and release of antimicrobial products is directly controlled by immune cell-derived IFN- $\gamma$. J. Exp. Med. 2014, 211, 1393-1405. [CrossRef]

26. Cantin, A.M.; North, S.L.; Hubbard, R.C.; Crystal, R.G. Normal alveolar epithelial lining fluid contains high levels of glutathione. J. Appl. Physiol. 1987, 63, 152-157. [CrossRef]

27. Cross, C.E.; van der Vliet, A.; O’Neill, C.A.; Louie, S.; Halliwell, B. Oxidants, antioxidants, and respiratory tract lining fluids Environ. Health Perspect. 1994, 102, 185-191. [CrossRef] [PubMed]

28. Jahani, S.; Shakiba, A.; Jahani, L. The antimicrobial effect of lactoferrin on gram-negative and gram-positive bacteria. Int. J. Infect. 2015, 2, e27954. [CrossRef]

29. Mateos, F.; Brock, J.H.; Pérez-Arellano, J.L. Iron metabolism in the lower respiratory tract. Thorax 1998, 53, 594-600. [CrossRef] [PubMed]

30. Matzinger, P. Tolerance, danger, and the extended family. Annu. Rev. Immunol. 1994, 12, 991-1045. [CrossRef]

31. Janeway, C.A.; Medzhitov, R. Innate immune recognition. Annu. Rev. Immunol. 2002, 20, 197-216. [CrossRef] 
32. Suresh, R.; Moser, D.M. Pattern recognition in innate immunity, host defense, and immunopathology. Adv. Physiol. Educ. 2013, 37, 284-291. [CrossRef]

33. Annunziato, F.; Romagnani, C.; Romagnani, S. The 3 major types of innate and adaptive cell-mediated effector immunity. J. Allergy Clin. Immunol. 2015, 135, 625-635. [CrossRef] [PubMed]

34. Hams, E.; Armstrong, M.E.; Barlow, J.L.; Saunders, S.P.; Schwartz, C.; Cooke, G.; Fahy, R.J.; Crotty, T.B.; Hirani, N.; Flynn, R.J.; et al. IL25 and type 2 innate lymphoid cells induce pulmonary fibrosis. Proc. Natl. Acad. Sci. USA 2014, 111, 367-372. [CrossRef] [PubMed]

35. Drake, L.Y.; Kita, H. IL-33: Biological properties, functions and roles in airway disease. Immunol. Rev. 2017, 278, 173-184. [CrossRef] [PubMed]

36. Scott, I.C.; Majithiya, J.B.; Sanden, C.; Thornton, P.; Sanders, P.N.; Moore, T.; Guscott, M.; Corkill, D.J.; Erjefält, J.S.; Cohen, S. Interleukin-33 is activated by allergen- and necrosis-associated proteolytic activities during epithelial damage. Sci. Rep. 2018, 8 , 3363. [CrossRef] [PubMed]

37. Roan, F.; Obata-Ninomiya, K.; Ziegler, S.F. Epithelial cell-derived cytokines: More than just signaling the alarm. J. Clin. Investig. 2019, 129, 1441-1451. [CrossRef]

38. Bolscher, B.G.J.M.; Plat, H.; Wever, R. Some properties of human eosinophil peroxidase, a comparison with other peroxidases. Biochim. Biophys. Acta 1984, 784, 177-186. [CrossRef]

39. Singh, A.M.; Singh, N.; Sharma, S.; Singh, S.B.; Kaur, P.; Bhushan, A.; Srinivasan, A.; Singh, T.P. Crystal structure of lactoperoxidase at $2.4 \AA$ A resolution. J. Mol. Biol. 2008, 376, 1060-1075. [CrossRef]

40. Furtmüller, P.G.; Zederbauer, M.; Jantschko, W.; Helm, M.; Bogner, C.; Jakopitsch, C.; Obinger, C. Active site structure and catalytic mechanisms of human peroxidases. Arch. Biochem. Biophys. 2006, 445, 199-213. [CrossRef]

41. Faraji, N.; Zhang, Y.; Ray, A.K. Optimization of lactoperoxidase and lactoferrin separation on an ion-exchange chromatography step. Separations 2017, 4, 10. [CrossRef]

42. Agner, K. Verdoperoxidase. Acta Physiol. Scand. 1941, 2 (Suppl. S8), 5-62.

43. Venge, P. Genomics and proteomics of the human eosinophil. In Eosinophils in Health and Disease; Lee, J.J., Rosenberg, H.F., Eds.; Academic Press: London, UK; San Diego, CA, USA; Cambridge, MA, USA; Oxford, UK, 2012; pp. 432-442. [CrossRef]

44. Cai, H.; Chuang, C.Y.; Hawkins, C.L.; Davies, M.J. Binding of myeloperoxidase to the extracellular matrix of smooth muscle cells and subsequent matrix modification. Sci. Rep. 2020, 10, 666. [CrossRef]

45. Oxvig, C.; Thomson, A.R.; Overgaard, M.T.; Sorensen, E.S.; Jojrup, P.; Bjerrum, M.J.; Gleich, G.J.; Sottrup-Jensen, L. Biochemical evidence for heme linkage through esters with Asp-93 and Glu-241 in human eosinophil peroxidase. The ester with Asp93 is only partially formed in vivo. J. Biol. Chem. 1999, 274, 16953-16958. [CrossRef] [PubMed]

46. Fiedler, T.J.; Davey, C.A.; Fenna, R.E. X-ray crystal structure and characterization of halide-binding sites of human myeloperoxidase at 1.8 Å resolution. J. Biol. Chem. 2000, 275, 11964-11971. [CrossRef]

47. Furtmüller, P.G.; Burner, U.; Obinger, C. Reaction of myeloperoxidase compound I with chloride, bromide, iodide, and thiocyanate. Biochemistry 1998, 37, 17923-17930. [CrossRef]

48. Furtmüller, P.G.; Burner, U.; Regelsberger, G.; Obinger, C. Spectral and kinetic studies on the formation of eosinophil peroxidase compound I and its reaction with halides and thiocyanate. Biochemistry 2000, 39, 15578-15584. [CrossRef]

49. Wever, R.; Kast, W.M.; Kasinoedin, J.H.; Boelens, R. The peroxidation of thiocyanate catalysed by myeloperoxidase and lactoperoxidase. Biochim. Biophys. Acta 1982, 709, 212-219. [CrossRef]

50. Dolphin, D.; Forman, A.; Borg, D.C.; Fajer, J.; Felton, R.H. Compound I of catalase and horseradish peroxidase: $\pi$-cation radicals. Proc. Natl. Acad. Sci. USA 1971, 68, 614-618. [CrossRef] [PubMed]

51. Furtmüller, P.G.; Jantschko, W.; Regelsberger, G.; Jakopitsch, C.; Arnhold, J.; Obinger, C. Reactions of lactoperoxidase compound I with halides and thiocyanate. Biochemistry 2002, 41, 11895-11900. [CrossRef] [PubMed]

52. Fielding, A.J.; Singh, R.; Boscolo, B.; Loewen, P.C.; Ghibaudi, E.M.; Ivancich, A. Intramolecular electron transfer versus substrate oxidation in lactoperoxidase: Investigation of radical intermediates by stopped-flow absorption spectrophotometry and (9-285 $\mathrm{GHz}$ ) electron paramagnetic resonance spectroscopy. Biochemistry 2008, 47, 9781-9792. [CrossRef]

53. Marquez, L.A.; Dunford, H.B. Kinetic of oxidation of tyrosine and dityrosine by myeloperoxidase compounds I and II. J. Biol. Chem. 1995, 270, 30434-30440. [CrossRef]

54. Burner, U.; Jantschko, W.; Obinger, C. Kinetic of oxidation of aliphatic and aromatic thiols by myeloperoxidase compounds I and II. FEBS Lett. 1999, 43, 290-296. [CrossRef]

55. Burner, U.; Furtmüller, P.G.; Kettle, A.J.; Koppenol, W.H.; Obinger, C. Mechanism of reaction of myeloperoxidase with nitrite. J. Biol. Chem. 2000, 275, 20597-20601. [CrossRef] [PubMed]

56. Jantschko, W.; Furtmüller, P.G.; Allegra, M.; Livrea, M.A.; Jakopitsch, C.; Regelsberger, G.; Obinger, C. Redox intermediates of plant and mammalian peroxidases: A comparative transient-kinetic study of their reactivity toward indole derivatives. Arch. Biochem. Biophys. 2002, 398, 12-22. [CrossRef] [PubMed]

57. Meotti, F.C.; Jameson, G.N.L.; Turner, R.; Harwood, T.D.; Stockwell, S.; Rees, M.D.; Thomas, S.R.; Kettle, A.J. Urate as a physiological substrate for myeloperoxidase. Implications for hyperuricemia and inflammation. J. Biol. Chem. 2011, 286, 12901-12911. [CrossRef]

58. Gau, J.; Furtmüller, P.G.; Obinger, C.; Prévost, M.; van Antwerpen, P.; Arnhold, J.; Flemmig, J. Flavonoids as promoters of the (pseudo)halogenating activity of lactoperoxidase and myeloperoxidase. Free Radic. Biol. Med. 2016, 97, 307-319. [CrossRef] 
59. Spalteholz, H.; Furtmüller, P.G.; Jakopitsch, C.; Obinger, C.; Schewe, T.; Sies, H.; Arnhold, J. Kinetic evidence for rapid oxidation of (-)-epicatechin by human myeloperoxidase. Biochem. Biophys. Res. Commun. 2008, 371, 810-813. [CrossRef]

60. Kirchner, T.; Flemmig, J.; Furtmüller, P.G.; Obinger, C.; Arnhold, J. (-)-Epicatechin enhances the chlorinating activity of human myeloperoxidase. Arch. Biochem. Biophys. 2010, 495, 21-27. [CrossRef]

61. Bolscher, B.G.J.M.; Zoutberg, G.R.; Cuperus, R.A.; Wever, R. Vitamin C stimulates the chlorinating activity of human myeloperoxidase. Biochim. Biophys. Acta 1984, 784, 189-191. [CrossRef]

62. Dunford, H.B.; Hsuanyu, Y. Kinetics of oxidation of serotonin by myeloperoxidase compounds I and II. Biochem. Cell Biol. 1999, 77, 449-457. [CrossRef]

63. Kettle, A.J.; Anderson, R.F.; Hampton, M.B.; Winterbourn, C.C. Reactions of superoxide with myeloperoxidase. Biochemistry 2007, 46, 4888-4897. [CrossRef]

64. Davies, M.J.; Hawkins, C.L.; Pattison, D.I.; Rees, M.D. Mammalian heme peroxidases: From molecular mechanisms to health implications. Antioxid. Redox Signal. 2008, 10, 1199-1234. [CrossRef] [PubMed]

65. Rigoni, A.; Poulsom, R.; Jeffery, R.; Mehta, S.; Lewis, A.; Yau, C.; Giannoulatou, E.; Feakins, R.; Lindsay, J.O.; Colombo, M.P.; et al. Separation of dual oxidase 2 and lactoperoxidase expression in intestinal crypts and species differences may limit hydrogen peroxide scavenging during mucosal healing in mice and humans. Inflamm. Bowel Dis. 2018, 24, 136-148. [CrossRef] [PubMed]

66. Yamakaze, J.; Lu, Z. Deletion of the lactoperoxidase gene causes multisystem inflammation and tumors in mice. Sci. Rep. 2021, 11, 12429. [CrossRef] [PubMed]

67. Thomas, E.L. Lactoperoxidase-catalyzed oxidation of thiocyanate: Equilibria between oxidized forms of thiocyanate. Biochemistry 1981, 20, 3273-3280. [CrossRef]

68. Nagy, P.; Jameson, G.N.; Winterbourn, C.C. Kinetics and mechanisms of the reaction of hypothiocyanaous acid with 5-thio-2nitrobenzoic acid and reduced glutathione. Chem. Res. Toxicol. 2009, 22, 1833-1840. [CrossRef]

69. Pattison, D.I.; Davies, M.J. Absolute rate constants for the reaction of hypochlorous acid with protein side chains and peptide bonds. Chem. Res. Toxicol. 2001, 14, 453-464. [CrossRef]

70. Hawkins, C.L.; Pattison, D.I.; Davies, M.J. Hypochlorite-induced oxidation of amino acids, peptides, and proteins. Amino Acids 2003, 25, 259-274. [CrossRef]

71. Pattison, D.I.; Davies, M.J. Kinetic analysis of the reaction of hypobromous acid with protein components: Implication for cellular damage and the use of 3-bromotyrosine as a marker of oxidative stress. Biochemistry 2004, 43, 4799-4809. [CrossRef]

72. Skaff, O.; Pattison, D.I.; Davies, M.J. Hypothiocyanous acid reactivity with low-molecular-mass and protein thiols: Absolute rate constants and assessment of biological relevance. Biochem. J. 2009, 422, 111-117. [CrossRef]

73. Skaff, O.; Pattison, D.I.; Morgan, P.E.; Bachana, R.; Jain, V.K.; Priyadarsini, I.; Davies, M.J. Selenium-containing amino acids are targets for myeloperoxidase-derived hypothiocyanous acid: Determination of absolute rate constants and implications for biological damage. Biochem. J. 2012, 441, 305-316. [CrossRef]

74. Hawkins, C.L. The role of hypothiocyanous acid (HOSCN) in biological systems. Free Radic. Res. 2009, 43, 1147-1158. [CrossRef]

75. Barrett, T.J.; Hawkins, C.L. Hypothiocyanous acid: Benign or deadly? Chem. Res. Toxicol. 2012, 25, 263-273. [CrossRef]

76. Chandler, J.D.; Nichols, D.P.; Nick, J.A.; Hondal, R.J.; Day, B.J. Selective metabolism of hypothiocyanous acid by mammalian thioredoxin reductase promotes lung innate immunity and antioxidant defense. J. Biol. Chem. 2013, 288, 18421-18428. [CrossRef]

77. Dastur, D.K.; Quadros, E.V.; Wadia, N.H.; Desai, M.M.; Bharucha, E.P. Effect of vegetarianism and smoking on vitamin B12, thiocyanate, and folate levels in the blood of normal subjects. Br. Med. J. 1972, 3, 260-263. [CrossRef] [PubMed]

78. Rehak, N.N.; Cecco, S.A.; Niemala, J.E.; Elin, R.J. Thiocyanate in smokers interferes with Nova magnesium ion-selective electrode. Clin. Chem. 1997, 43, 1595-1600. [CrossRef] [PubMed]

79. Fragoso, M.A.; Fernandez, V.; Forteza, R.; Randell, S.H.; Salathe, M.; Conner, G.E. Transcellular thiocyanate transport by human airway epithelia. J. Physiol. 2004, 561, 183-194. [CrossRef]

80. Gottardi, W. Iodine and disinfection: Theoretical study on the mode of action, efficiency, stability, and analytical aspects in the aqueous system. Arch. Pharm. Weinheim. 1999, 332, 151-157. [CrossRef]

81. Rendl, J.; Luster, M.; Reiners, C. Serum inorganic iodide determined by paired-ion-reverse-phase HPLC with electrochemical detection. J. Liq. Chromatogr. Relat. Technol. 1997, 20, 1445-1459. [CrossRef]

82. San Gabriel, P.T.; Liu, Y.; Schroeder, A.L.; Zoellner, H.; Chami, B. The role of thiocyanate in modulating myeloperoxidase activity during disease. Int. J. Mol. Sci. 2020, 21, 6450. [CrossRef] [PubMed]

83. Pedemonte, N.; Caci, E.; Sondo, E.; Caputo, A.; Rhoden, K.; Pfeffer, U.; Di Candia, M.; Bandettini, R.; Ravazzolo, R.; ZegarraMoran, O.; et al. Thiocyanate transport in resting and IL-4-stimulated human bronchial epithelial cells: Role of pendrin and anion channels. J. Immunol. 2007, 78, 5144-5153. [CrossRef]

84. Tenovuo, J.; Mäkinen, K.K. Concentration of thiocyanate and ionizable iodine in saliva of smokers and nonsmokers. J. Dent. Res. 1976, 55, 661-663. [CrossRef]

85. Schultz, C.P.; Ahmed, M.K.; Dawes, C.; Mantsch, H.H. Thiocyanate levels in human saliva: Quantitation by Fourier transform infrared spectroscopy. Anal. Biochem. 1996, 240, 7-12. [CrossRef] [PubMed]

86. Van Haeringen, N.J.; Ensink, F.T.; Glasius, E. The peroxidase-thiocyanate-hydrogen peroxide system in tear fluid and saliva of different species. Exp. Eye Res. 1979, 28, 343-347. [CrossRef] 
87. Fischer, A.J.; Lennemann, N.J.; Krishnamurthy, S.; Pócza, P.; Durairaj, L.; Launspach, J.L.; Rhein, B.A.; Wohlford-Lenane, C.; Lorentzen, D.; Bánfi, B.; et al. Enhancement of respiratory antiviral defenses by the oxidation of iodide. Am. J. Respir. Cell Mol. Biol. 2011, 45, 874-881. [CrossRef] [PubMed]

88. Wijkstrom-Frei, C.; El-Chemaly, S.; Ali-Rachedi, R.; Gerson, C.; Cobas, M.A.; Forteza, R.; Salathe, M.; Conner, G.E. Lactoperoxidase and human airway host defense. Am. J. Respir. Cell Mol. Biol. 2003, 29, 206-212. [CrossRef]

89. Geiszt, M.; Witta, J.; Baffi, J.; Lekstrom, K.; Leto, T.L. Dual oxidases represent novel hydrogen peroxide sources supporting mucosal surface host defense. FASEB J. 2003, 17, 1502-1504. [CrossRef]

90. Schwarzer, C.; Machen, T.E.; Illek, B.; Fischer, H. NADPH oxidase-dependent acid production in airway epithelial cells. J. Biol. Chem. 2004, 279, 36454-36461. [CrossRef] [PubMed]

91. Forteza, R.; Salathe, M.; Miot, F.; Forteza, R.; Conner, G.E. Regulated hydrogen peroxide production by Duox in human airway epithelial cells. Am. J. Respir. Cell Mol. Biol. 2005, 32, 462-469. [CrossRef]

92. Olson, J.S.; Ballou, D.P.; Palmer, G.; Massey, V. The reaction of xanthine oxidase with molecular oxygen. J. Biol. Chem. 1974, 249, 4350-4362. [CrossRef]

93. Pinamonti, S.; Muzzoli, M.; Chicca, M.C.; Papi, A.; Ravenna, F.; Fabbri, L.M.; Ciaccia, A. Xanthine oxidase activity in bronchoalveolar lavage fluid from patients with chronic obstructive pulmonary disease. Free Radic. Biol. Med. 1996, $21,147-155$. [CrossRef]

94. Ichinose, M.; Sugiura, H.; Yamagata, S.; Koarai, A.; Tomaki, M.; Ogawa, H.; Komaki, Y.; Barnes, P.J.; Shirato, K.; Hattori, T. Xanthine oxidase inhibition reduces reactive nitrogen species production in COPD airways. Eur. Respir. J. 2003, $22,457-461$. [CrossRef] [PubMed]

95. Imlay, J.A. Cellular defenses against superoxide and hydrogen peroxide. Annu. Rev. Biochem. 2008, 77, 755-776. [CrossRef]

96. Garcia-Mendoza, A.; Liebana, J.; Castillo, A.M.; de la Higuera, A.; Piedrola, G. Evaluation of the capacity of oral streptococci to produce hydrogen peroxide. J. Med. Microbiol. 1993, 39, 434-439. [CrossRef]

97. Erttmann, S.F.; Gekara, N.O. Hydrogen peroxide release by bacteria suppresses inflammasome-dependent innate immunity. Nat. Commun. 2019, 10, 3493. [CrossRef] [PubMed]

98. Rhee, S.G.; Kang, S.W.; Chang, T.S.; Jeong, W.; Kim, K. Peroxiredoxin, a novel family of peroxidases. IUMBM Life 2001, 52, 35-41. [CrossRef]

99. Brigelius-Flohé, R.; Maiorino, M. Glutathione peroxidase. Biochim. Biophys. Acta 2013, 1830, 3289-3303. [CrossRef] [PubMed]

100. Glorieux, C.; Calderon, P.B. Catalase, a remarkable enzyme: Targeting the oldest antioxidant enzyme to find a new cancer treatment approach. Biol. Chem. 2017, 398, 1095-1108. [CrossRef] [PubMed]

101. Avissar, N.; Finkelstein, J.N.; Horowitz, S.; Willey, J.C.; Coy, E.; Frampton, M.W.; Watkins, R.H.; Khullar, P.; Xu, Y.L.; Cohen, H.J. Extracellular glutathione peroxidase in human lung epithelial ining fluid and in lung cells. Am. J. Physiol. 1996, 270, L173-L182. [CrossRef]

102. Koppenol, W.H. The centennial of the Fenton reaction. Free Radic. Biol. Med. 1993, 15, 645-651. [CrossRef]

103. Wardman, P.; Candeias, L.P. Fenton chemistry: An introduction. Radiat. Res. 1996, 145, 523-531. [CrossRef]

104. Crichton, R.R.; Wilmet, S.; Legssyer, R.; Ward, R.J. Molecular and cellular mechanisms of iron homeostasis and toxicity in mammalian cells. J. Inorg. Biochem. 2002, 91, 9-18. [CrossRef]

105. Ponka, P. Cellular iron metabolism. Kidney Int. 1999, 55, S2-S11. [CrossRef]

106. Metzler, K.D.; Fuchs, T.A.; Nauseef, W.M.; Reumaux, D.; Roesler, J.; Schulze, I.; Wahn, V.; Papyannopoulos, V.; Zychlinsky, A. Myeloperoxidase is required for neutrophil extracellular trap formation: Implications for innate immunity. Blood 2011, 117, 953-959. [CrossRef]

107. Brinkmann, V.; Reichard, U.; Goosmann, C.; Fauler, B.; Uhlemann, Y.; Weiss, D.S.; Weinrauch, Y.; Zychlinsky, A. Neutrophil extracellular traps kill bacteria. Science 2004, 303, 1532-1535. [CrossRef] [PubMed]

108. Urban, C.F.; Emert, D.; Schmid, M.; Abu-Abed, U.; Goosmann, C.; Nacken, W.; Brinkmann, V.; Jungblut, P.R.; Zychlinsky, A. Neutrophil extracellular traps contain calprotectin, a cytosolic protein complex involved in host defense against Candida albicans. PLoS Pathog. 2009, 5, 1000639. [CrossRef]

109. Papayannopoulos, Y.; Zychlinsky, A. NETs: A new strategy for using old weapons. Trends Immunol. 2009, 30, 513-521. [CrossRef]

110. Urban, C.F.; Reichard, U.; Brinkmann, V.; Zychlinsky, A. Neutrophil extracellular traps capture and kill Candida albicans yeast and hyphal forms. Cell Microbiol. 2006, 8, 668-676. [CrossRef] [PubMed]

111. Matheson, M.R.; Wong, P.S.; Travis, J. Enzymatic inactivation of human alpha-1 proteinase inhibitor by neutrophil myeloperoxidase. Biochem. Biophys. Res. Commun. 1979, 88, 402-409. [CrossRef]

112. Tiruppathi, C.; Naqvi, T.; Wu, Y.; Vogel, S.M.; Minshall, R.D.; Malik, A.B. Albumin mediates the transcytosis of myeloperoxidase by means of caveolae in endothelial cells. Proc. Natl. Acad. Sci. USA 2004, 101, 7699-7704. [CrossRef] [PubMed]

113. Zheng, L.; Nukuna, B.; Brennan, M.-L.; Sun, M.; Goormastic, M.; Settle, M.; Schmitt, X.; Fu, L.; Thomson, L.; Fox, P.L.; et al. Apolipoprotein A-1 is a selective target for myeloperoxidase-catalyzed oxidation and functional impairment in subjects with cardiovascular disease. J. Clin. Investig. 2004, 114, 529-541. [CrossRef] [PubMed]

114. Salavej, P.; Spalteholz, H.; Arnhold, J. Modification of amino acid residues in human serum albumin by myeloperoxidase. Free Radic. Biol. Med. 2006, 40, 516-525. [CrossRef] [PubMed] 
115. Malle, E.; Marsche, G.; Panzenboeck, U.; Sattler, W. Myeloperoxidase-mediated oxidation of high-density lipoproteins: Fingerprints of newly recognized potential proatherogenic lipoproteins. Arch. Biochem. Biophys. 2006, 45, 245-255. [CrossRef] [PubMed]

116. Nybo, T.; Cai, H.; Chuang, C.Y.; Gamon, L.F.; Rogowska-Wrzesinska, A.; Davies, M.J. Chlorination and oxidation of human plasma fibronectin by myeloperoxidase-derived oxidants, and its consequences for smooth muscle cell function. Redox Biol. 2018, 19, 388-400. [CrossRef]

117. Vanichkitrungruang, S.; Chuang, C.Y.; Hawkins, C.L. Myeloperoxidase-derived damage to human plasma fibronectin: Modulation by protein binding and thiocyanate ions $\left(\mathrm{SCN}^{-}\right)$. Redox Biol. 2020, 36, 101641. [CrossRef]

118. Baldus, S.; Eiserich, J.P.; Mani, A.; Castrom, L.; Figueroa, M.; Chumley, P.; Ma, W.; Tousson, A.; White, R.; Bullard, D.C.; et al. Endothelial transcytosis of myeloperoxidase confers specificity to vascular ECM proteins as targets for tyrosine nitration. J. Clin. Investig. 2001, 108, 1759-1770. [CrossRef] [PubMed]

119. Eiserich, J.P.; Baldus, S.; Brennan, M.-L.; Ma, W.; Zhang, C.; Tousson, A.; Castro, L.; Lusis, A.J.; Nauseef, W.M.; White, C.R.; et al. Myeloperoxidase, a leukocyte-derived vascular NO oxidase. Science 2002, 196, 2391-2394. [CrossRef]

120. van der Veen, B.S.; de Winther, M.P.; Heeringa, P. Myeloperoxidase: Molecular mechanisms and their relevance to human health and disease. Antioxid. Redox Signal. 2009, 11, 2899-2937. [CrossRef]

121. Lefkowitz, D.L.; Mone, J.; Lefkowitz, S.S. Myeloperoxidase: The good, the bad, and the ugly. Curr. Immunol. Rev. 2010, 6, 123-129. [CrossRef]

122. Khan, A.A.; Alsahli, M.A.; Rahmani, A.H. Myeloperoxidase as an active biomarker: Recent biochemical and pathological perspectives. Med. Sci. 2018, 6, 33. [CrossRef]

123. Jennette, J.C.; Falk, R.J.; Hu, P.; Xiao, H. Pathogenesis of anti-neutrophil cytoplasmic autoantibody associated small vessel vasculitis. Annu. Rev. Pathol. Mech. Dis. 2013, 8, 139-160. [CrossRef] [PubMed]

124. Jennette, J.C.; Nachman, P.H. ANCA glomerulonephritis and vasculitis. Clin. J. Am. Soc. Nephrol. 2017, 12, 1680-1691. [CrossRef] [PubMed]

125. Greenan, K.; Vassallo, D.; Chinnadurai, R.; Ritchie, J.; Shepard, K.; Green, A.; Ponnusamy, A.; Sinha, S. Respiratory manifestations of ANCA-associated vasculitis. Clin. Respir. J. 2018, 12, 57-61. [CrossRef] [PubMed]

126. Klion, A.D.; Nutman, T.B. The role of eosinophils in host defense against helminth parasites. J. Allergy Clin. Immunol. 2004, 113, 30-37. [CrossRef]

127. Yasuda, K.; Kuroda, E. Role of eosinophils in protective immunity against secondary nematode infections. Immunol. Med. 2019, 42, 148-155. [CrossRef]

128. Strandmark, J.; Rausch, S.; Hartmann, S. Eosinophils in homeostasis and their contrasting roles during inflammation and helminth infections. Crit. Rev. Immunol. 2016, 36, 193-238. [CrossRef] [PubMed]

129. Weiss, S.J.; Test, S.T.; Eckmann, C.M.; Roos, D.; Regiani, S. Brominating oxidants generated by human eosinophils. Science 1986, 234, 200-203. [CrossRef]

130. Romagnani, S. The role of lymphocytes in allergic disease. J. Allergy Clin. Immunol. 2000, 105, 399-408. [CrossRef]

131. Palm, N.W.; Rosenstein, R.K.; Medzhitov, R. Allergic host defences. Nature 2012, 484, 465-472. [CrossRef]

132. Yousefi, S.; Mihalache, C.; Kozlowski, E.; Schmid, I.; Simon, H.U. Viable neutrophils release mitochondrial DNA to form neutrophil extracellular traps. Cell Death Differ. 2009, 16, 1438-1444. [CrossRef]

133. Ueki, S.; Melo, R.C.N.; Ghiran, I.; Spencer, L.A.; Dvorak, A.M.; Weller, P.F. Eosinophil extracellular DNA trap cell death mediates lytic release of free secretion-competent eosinophil granules in humans. Blood 2013, 121, 2074-2083. [CrossRef] [PubMed]

134. Neves, J.S.; Weller, P.F. Functional extracellular eosinophil granules: Novel implications in eosinophil immunobiology. Curr. Opin. Immunol. 2009, 21, 694-699. [CrossRef]

135. Borroso, M.V.; Gropillp, I.; Detoni, M.A.A.; Thompson-Souza, G.A.; Muniz, V.S.; Vasconcelos, C.R.I.; Figueiredo, R.T.; Melo, R.C.N.; Neves, J.S. Structural and signaling events driving Aspergillus fumigatus-induced human eosinophil extracellular trap release. Front. Microbiol. 2021, 12, 633696. [CrossRef] [PubMed]

136. Fraser-Pitt, D.; O’Neil, D. Cystic fibrosis—a multiorgan protein misfolding disease. Future Sci. OA 2015, FSO57. [CrossRef] [PubMed]

137. Kerem, B.; Rommens, J.M.; Buchanan, J.A.; Markiewicz, D.; Cox, T.K.; Chakravarti, A.; Buchwald, M.; Tsui, L.C. Identification of the cystic fibrosis gene: Genetic analysis. Science 1989, 245, 1073-1080. [CrossRef]

138. Kogan, I.; Ramjeesingh, M.; Li, C.; Kidd, J.F.; Wang, Y.; Leslie, E.M.; Cole, S.P.; Bear, C.E. CFTR directly mediates nucleotideregulated glutathione flux. Embo J. 2003, 22, 1981-1989. [CrossRef] [PubMed]

139. Conner, G.E.; Wijkstrom-Frei, C.; Randell, S.H.; Fernandez, V.E.; Salathe, M. The lactoperoxidase system links anion transport to host defense in cystic fibrosis. FEBS Lett. 2007, 581, 271-278. [CrossRef]

140. Paradiso, A.M.; Coakley, R.D.; Boucher, R.C. Polarized distribution of $\mathrm{HCO}_{3}{ }^{-}$transport in human normal and cystic fibrosis nasal epithelia. J. Physiol. 2003, 548, 203-218. [CrossRef]

141. Boucher, R.C. New concepts of the pathogenesis of cystic fibrosis lung disease. Eur. Respir. J. 2004, 23, 146-158. [CrossRef]

142. Moskwa, P.; Lorentzen, D.; Excoffon, K.J.D.A.; Zabner, J.; McCray, P.B., Jr.; Nauseef, W.M.; Dupuy, C.; Bánfi, B. A novel host defense system of airways is defective in cystic fibrosis. Am. J. Respir. Crit. Care Med. 2007, 175, 174-183. [CrossRef] 
143. Lorentzen, D.; Durairaj, L.; Pezzulo, A.A.; Nakano, Y.; Launspach, J.; Stoltz, D.A.; Zamba, G.; McCray, P.B., Jr.; Zabner, J.; Welsh, M.J.; et al. Concentration of the antibacterial precursor thiocyanate in cystic fibrosis airway secretions. Free Radic. Biol. Med. 2011, 50, 1144-1150. [CrossRef]

144. Nakagami, Y.; Favoreto, S.J.; Zhen, G.; Park, S.W.; Nguyenvu, L.T.; Kuperman, D.A.; Dolganov, G.M.; Huang, X.; Boushey, H.A.; Avila, P.C.; et al. The epithelial anion transporter pendrin is induced by allergy and rhinovirus infection, regulates airway surface liquid, and increases airway reactivity and inflammation in an asthma model. J. Immunol. 2008, 181, 2203-2210. [CrossRef]

145. Nakao, I.; Kanaji, S.; Ohta, S.; Matsushita, H.; Arima, K.; Yuyama, N.; Yamaya, M.; Nakayama, K.; Kubo, H.; Watanabe, M.; et al. Identification of pendrin as a common mediator for mucus production in bronchial asthma and chronic obstructive pulmonary disease. J. Immunol. 2008, 180, 6262-6269. [CrossRef] [PubMed]

146. Linsdell, P.; Tabcharani, J.A.; Rommens, J.M.; Hou, Y.X.; Chang, X.B.; Tsui, L.C.; Riordan, J.R.; Hanrahan, J.W. Permeability of wild-type and mutant cystic fibrosis transmembrane conductance regulator chloride channels to polyatomic anions. J. Gen. Physiol. 1997, 110, 355-364. [CrossRef]

147. Frizzell, R.A.; Hanrahan, J.W. Physiology of epithelial chloride and fluid secretion. Cold Spring Harb. Perspect. Med. 2012, 2, a009563. [CrossRef]

148. Kyle, H.; Ward, J.P.; Widdicombe, J.G. Control of pH of airway surface liquid of the ferret trachea in vitro. J. Appl. Physiol. 1990, 68, 135-140. [CrossRef] [PubMed]

149. Song, Y.; Salinas, D.; Nielson, D.W.; Verkman, A.S. Hyperacidity of secreted fluid from submucosal glands in early cystic fibrosis. Am. J. Physiol. Cell Physiol. 2006, 290, C741-C749. [CrossRef]

150. Cho, D.-Y.; Hwang, P.H.; Illek, B.; Fischer, H. Acid and base secretion in freshly excised nasal tissue from cystic fibrosis patients with $\Delta$ F508 mutation. Int. Forum Allergy Rhinol. 2011, 1, 123-127. [CrossRef]

151. Xu, Y.; Szép, S.; Lu, Z. The antioxidant role of thiocyanate in the pathogenesis of cystic fibrosis and other inflammation-related diseases. Proc. Natl. Acad. Sci. USA 2009, 106, 20515-20519. [CrossRef]

152. Hill, D.B.; Long, R.F.; Kissner, W.J.; Atieh, E.; Garbarine, I.C.; Markovetz, M.R.; Fontana, N.C.; Christy, M.; Habibpour, M.; Tarran, R.; et al. Pathological mucus and impaired mucus clearance in cystic fibrosis patients result from increased concentration, not altered pH. Eur. Respir. J. 2018, 52, 1801297. [CrossRef]

153. Coakley, R.D.; Grubb, B.R.; Paradiso, A.M.; Gatzy, J.T.; Johnson, L.G.; Kreda, S.M.; O’Neal, W.K.; Boucher, R.C. Abnormal surface liquid $\mathrm{pH}$ regulation by cultured cystic fibrosis bronchial epithelium. Proc. Natl. Acad. Sci. USA 2003, 100, 16083-16088. [CrossRef] [PubMed]

154. Kim, D.; Liao, J.; Hanrahan, J.W. The buffer capacity of airway epithelial secretions. Front. Physiol. 2014, 5, 188. [CrossRef] [PubMed]

155. Tang, X.X.; Ostedgaard, L.S.; Hoegger, M.J.; Moninger, T.O.; Karp, P.H.; McMenimen, J.D.; Choudhury, B.; Varki, A.; Stoltz, D.A.; Welsh, M.J. Acidic pH increases airway surface liquid viscocity in cystic fibrosis. J. Clin. Investig. 2016, 126, 879-891. [CrossRef]

156. Veerman, E.C.; Valentijn-Benz, M.; Nieuw Amerongen, A.V. Viscosity of human salivary mucins: Effect of $\mathrm{pH}$ and ionic strength and role of sialic acid. J. Biol. Buccale 1989, 17, 297-306. [PubMed]

157. Ridley, C.; Kouvatsos, N.; Raynal, B.D.; Howard, M.; Collins, R.F.; Desseyn, J.-L.; Jowitt, T.A.; Baldock, C.; Davis, C.W.; Hardingham, T.E.; et al. Assembly of the respiratory mucin MUC5B: A new model for a gel-forming mucin. J. Biol. Chem. 2014, 289, 16409-16420. [CrossRef]

158. Lyczak, J.B.; Cannon, C.L.; Pier, G.B. Lung infections associated with cystic fibrosis. Clin. Microbiol. Rev. 2002, 15, 194-222. [CrossRef]

159. Pezzulo, A.A.; Tang, X.X.; Hoegger, M.J.; Alaiwa, M.H.A.; Ramachandran, S.; Moninger, T.O.; Karp, P.H.; Wohlford-Lenane, C.L.; Haagsman, H.P.; van Eijk, M.; et al. Reduced airway surface pH impairs bacterial killing in the porcine cystic fibrosis lung. Nature 2012, 487, 109-113. [CrossRef]

160. Sly, P.D.; Gangell, C.L.; Chen, L.; Ware, R.S.; Ranganathan, S.; Mott, L.S.; Murray, C.P.; Stick, S.M. Risk factors for bronchiectasis in children with cystic fibrosis. N. Engl. J. Med. 2013, 368, 1963-1970. [CrossRef]

161. Stoltz, D.A.; Meyerholz, D.K.; Welsh, M.J. Origin of cystic fibrosis lung disease. N. Engl. J. Med. 2015, 372, 351-362. [CrossRef] [PubMed]

162. Chandler, J.D.; Margoroli, C.; Horati, H.; Kilgore, M.B.; Veltman, M.; Liu, H.K.; Taurone, A.J.; Peng, L.; Guglani, L.; Uppal, K.; et al. Myeloperoxidase oxidation of methionine associates with early cystic fibrosis lung disease. Eur. Respir. J. $2018,52,1801118$. [CrossRef]

163. Yuan, S.; Hollinger, M.; Lachowicz-Scroggins, M.E.; Kerr, S.C.; Dunican, E.M.; Daniel, B.M.; Ghosh, S.; Erzurum, S.C.; Willard, B.; Hazen, S.L.; et al. Oxidation increases mucin polymer cross-links to stiffen airway mucus gel. Sci. Transl. Med. 2015, 7, 276 ra27. [CrossRef]

164. Van der Vliet, A.; Nguyen, M.N.; Shigenaga, M.K.; Eiserich, J.P.; Marelich, G.P.; Cross, C.E. Myeloperoxidase and protein oxidation in cystic fibrosis. Am. J. Physiol. Lung Cell Mol. Physiol. 2000, 279, L537-L546. [CrossRef]

165. van Dalen, C.J.; Whitehouse, M.W.; Winterbourn, C.C.; Kettle, A.J. Thiocyanate and chloride as competing substrates for myeloperoxidase. Biochem. J. 1997, 327, 487-492. [CrossRef]

166. Ashby, M.T.; Carlson, A.C.; Scott, M.J. Redox buffering of hypochlorous acid by thiocyanate in physiologic fluids. J. Am. Chem. Soc. 2004, 126, 15976-15977. [CrossRef] [PubMed] 
167. Von Klitzing, R.; Möhwald, H. Proton concentration profile in ultrathin polyelectrolyte films. Langmuir 1995, 11, 3554-3559. [CrossRef]

168. Zhang, Y.; Tsitkov, S.; Hess, H. Proximity does not contribute to activity enhancement in the glucose-horseradish peroxidase cascade. Nat. Commun. 2016, 7, 13982. [CrossRef]

169. Thomson, E.; Brennan, S.; Senthilmohan, R.; Gangell, C.L.; Chapman, A.L.; Sly, P.D.; Kettle, A.J. Identifying peroxidase and their oxidants in the early pathology of cystic fibrosis. Free Radic. Biol. Med. 2010, 49, 1354-1360. [CrossRef]

170. Hair, P.S.; Sass, L.A.; Krishna, N.K.; Cunnion, K.M. Inhibition of myeloperoxidase activity in cystic fibrosis sputum by peptide inhibitor of complement C1 (PIC1). PLoS ONE 2017, 12, e0170203. [CrossRef] [PubMed]

171. Spalteholz, H.; Panasenko, O.M.; Arnhold, J. Formation of reactive halide species by myeloperoxidase and eosinophil peroxidase Arch. Biochem. Biophys. 2006, 445, 225-234. [CrossRef]

172. Levine, A.P.; Duchen, M.R.; de Villiers, S.; Rich, P.R.; Segal, A.W. Alkalinity of neutrophil phagocytic vacuoles is modulated by HVCN1 and has consequences for myeloperoxidase activity. PLoS ONE 2015, 10, e0125906. [CrossRef]

173. Suzuki, S.; Ogawa, M.; Ohta, S.; Arima, K.; Nunomura, S.; Nanri, Y.; Mitamura, Y.; Yoshihara, T.; Nakamura, Y.; Yamauchi, K.; et al. The potential for repositioning anti-thyroid agents as anti-asthma drugs. J. Allergy Clin. Immunol. 2016, 138, $1458-1461$. [CrossRef] [PubMed]

174. Izuhara, K.; Suzuki, S.; Ogawa, M.; Nunomura, S.; Nanri, Y.; Mitamura, Y.; Yoshihara, T. The significance of hypothiocyanite production via the pendrin/DUOX/peroxidase pathway in the pathogenesis of asthma. Oxid. Med. Cell. Longev. 2017, 1054801. [CrossRef]

175. Suzuki, S.; Ogawa, M.; Ohta, S.; Arima, K.; Nunomura, S.; Nanri, Y.; Shiraishi, H.; Mitamura, Y.; Yoshihara, T.; Lee, J.J.; et al. Induction of airway allergic inflammation by hypothiocyanite via epithelial cells. J. Biol. Chem. 2016, 291, 27219-27227. [CrossRef] [PubMed]

176. Schuliga, M. NF-кB signaling in chronic inflammatory airway disease. Biomolecules 2015, 5, 1266-1283. [CrossRef]

177. Cayrol, C.; Girard, J.P. IL-33: An alarmin cytokine with crucial roles in innate immunity, inflammation and allergy. Curr. Opin. Immunol. 2014, 31, 31-37. [CrossRef]

178. Chan, B.C.L.; Lam, C.W.K.; Tam, L.-S.; Wong, C.K. IL33: Roles in allergic inflammation and therapeutic perspectives. Front. Immunol. 2019, 10, 364. [CrossRef]

179. Arlandson, M.; Decker, T.; Roongta, V.A.; Bonilla, L.; Mayo, K.H.; MacPherson, J.C.; Hazen, S.L.; Slungaard, A. Eosinophil peroxidase oxidation of thiocyanate: Characterization of major reaction products and a potential sulfhydryl-targeted cytotoxicity system. J. Biol. Chem. 2001, 276, 215-224. [CrossRef]

180. Wang, Z.; Nicholls, S.J.; Rodriguez, E.R.; Kummu, O.; Hörkkö, S.; Barnard, J.; Reynolds, W.F.; Topol, E.J.; DiDonato, J.A.; Hazen, S.L. Protein carbamylation links inflammation, smoking, uremia and atherogenesis. Nat. Med. 2007, 13, 1176-1184. [CrossRef] [PubMed]

181. Mydel, P.; Wang, Z.; Brisslert, M.; Hellvard, A.; Dahlberg, L.E.; Hazen, S.L.; Bokarewa, M. Carbamylation-dependent activation of T cells: A novel mechanism in the pathogenesis of autoimmune arthritis. J. Immunol. 2010, 184, 6882-6890. [CrossRef]

182. El-Gamal, D.; Rao, S.P.; Holzer, M.; Hallström, S.; Haybaeck, J.; Gauster, M.; Wadsack, C.; Kozina, A.; Frank, S.; Schicho, R.; et al. The urea decomposition product cyanate promotes endothelial dysfunction. Kidney Int. 2014, 86, 923-931. [CrossRef] [PubMed]

183. Wang, Z.; DiDonato, J.A.; Buffa, J.; Comhair, S.A.; Aronica, M.A.; Dweik, R.A.; Lee, N.A.; Lee, J.J.; Thomassen, M.J.; Kavuru, M.; et al. Eosinophil peroxidase catalyzed protein carbamylation participates in asthma. J. Biol. Chem. 2016, 291, 22118-22135. [CrossRef]

184. Wu, W.; Chen, Y.; Hazen, S.L. Eosinophil peroxidase nitrates protein tyrosyl residues: Implications for oxidative damage by nitrating intermediates in eosinophilic inflammatory disorders. J. Biol. Chem. 1999, 274, 25933-25944. [CrossRef]

185. Wu, W.; Chen, Y.; d'Avignon, A.; Hazen, S.L. 3-Bromotyrosine and 3,5-dibromotyrosine are major products of protein oxidation by eosinophil peroxidase: Potential markers for eosinophil-dependent tissue injury in vivo. Biochemistry 1999, 38, 3538-3548. [CrossRef]

186. Wu, W.; Samoszuk, M.K.; Comhair, S.A.; Thomassen, M.J.; Farver, C.F.; Dweik, R.A.; Kavuru, M.S.; Erzurum, S.C.; Hazen, S.L. Eosinophils generate brominating oxidants in allergen-induced asthma. J. Clin. Investig. 2000, 105, 1455-1463. [CrossRef]

187. Reber, A.J.; Chirkova, T.; Kim, J.H.; Cao, W.; Biber, R.; Shay, D.K.; Sambhara, S. Immunosenescence and challenges of vaccination against influenza in the aging population. Aging Dis. 2012, 3, 68-90. [PubMed]

188. Kampitak, T.; Suwanpimolkul, G.; Browne, S.; Suankratay, C. Anti-interferon- autoantibody and.opportunistic infections: Case series and review of the literature. Infection 2011, 39, 65-71. [CrossRef]

189. Segelmark, M.; Persson, B.; Hellmark, T.; Wieslander, J. Binding and inhibition of myeloperoxidase (MPO): A major function of ceruloplasmin? Clin. Exp. Immunol. 1997, 108, 167-174. [CrossRef]

190. Park, Y.S.; Suzuki, K.; Mumby, S.; Taniguchi, N.; Gutteridge, J.M.C. Antioxidant binding of caeruloplasmin to myeloperoxidase: Myeloperoxidase is inhibited, but oxidase, peroxidase, and immunoreactive properties of caeruloplasmin remain intact. Free Radic. Res. 2000, 33, 261-265. [CrossRef] [PubMed]

191. Sokolov, A.V.; Ageeva, K.V.; Pulina, M.O.; Cherkalina, O.S.; Samygina, V.R.; Vlasova, I.I.; Panasenko, O.M.; Zakharova, E.T.; Vasilyev, V.B. Ceruloplasmin and myeloperoxidase in complex affect the enzymatic properties of each other. Free Radic. Res. 2008, 42, 989-998. [CrossRef] [PubMed] 
192. Samygina, V.R.; Sokolov, A.V.; Bourenkov, G.; Petoukhov, M.V.; Pulina, M.O.; Zakharova, E.T.; Vasilyev, V.B.; Bartunik, H.; Svergun, D.I. Ceruloplasmin: Macromolecular assemblies with iron-containing acute phase proteins. PLoS ONE 2013, 8, e67145. [CrossRef] [PubMed]

193. Sokolov, A.V.; Kostevich, V.A.; Zakharova, E.T.; Samygina, V.R.; Panasenko, O.M.; Vasilyev, V.B. Interaction of ceruloplasmin with eosinophil peroxidase as compared to its interplay with myeloperoxidase: Reciprocal effect on enzymatic properties. Free Radic. Res. 2015, 49, 800-811. [CrossRef]

194. Pacht, E.R.; Davis, E.W. Role of transferrin and ceruloplasmin in antioxidant activity of lung epithelial lining fluid. J. Appl. Physiol. 1988, 64, 2092-2099. [CrossRef] [PubMed]

195. Tuzova, M.; Jean, J.-C.; Hughey, R.B.; Brown, L.A.S.; Cruikshank, W.W.; Hiratake, J.; Joyce-Brady, M. Inhibiting lung lining fluid glutathione metabolism with GGsTop as a novel treatment for asthma. Front. Pharmacol. 2014, 5, 179. [CrossRef]

196. Cantin, A.M.; North, S.L.; Hubbard, R.C.; Crystal, R.G. Glutathione and inflammatory disorders of the lung. Lung 1991, 169, 123-138. [CrossRef] [PubMed]

197. Roum, J.H.; Buhl, R.; McElvaney, N.G.; Borok, Z.; Crystal, R.G. Systemic deficiency of glutathione in cystic fibrosis. J. Appl. Physiol. 1993, 75, 2419-2424. [CrossRef] [PubMed] 